\title{
Squaring Undisclosed Agency Law with Contract Theory
}

\author{
Randy E. Barnett $\dagger$
}

The law of undisclosed agency has long been considered an anomaly of contract theory. While few disapprove of its content, this body of law does not appear to square with our theoretical understanding of contractual obligation. In this Article, Professor Barnett applies a "consent theory of contract" to explain and critically evaluate the law of undisclosed agency. After showing why standard contract theories have been unable to explain the established doctrine in this area, he analyzes the nexus of obligations arising from the consensual "triangular flow of rights" among the three parties to the paradigm undisclosed agency relationship. He then extends this analysis to treat several "hard cases." Professor Barnett concludes that the bulk of this spontaneously evolved body of law is theoretically sound; that the source of the long-standing apparent anomaly is the predominance of the promise-based theory underlying the action of assumpsit; and that judges' ability to develop good law in spite of the defciencies in the prevailing contract theories provides an insight into the appropriate roles of tradition and reason in generating law.

\section{INTRODUCTION}

The law of undisclosed agency concerns the following situation: $U P$ 's agent $A$ makes an agreement with $T$, but $U P$ 's existence and identity are unknown to $T$. UP is called the "undisclosed principal." What are the legal relations among these three actors? Do $A$ and $T$ have a valid contract? Can $T$ sue $U P$ for breach? Can $T$ refuse to perform when she discovers the identity of UP? Nearly every legal theorist who has considered the law of undisclosed agency from the point of view of contract theory has concluded that the established rules are anomalous. ${ }^{2}$ This has

$\dagger$ Professor of Law, Illinois Institute of Technology, Chicago-Kent College of Law. B.A. 1974, Northwestern University; J.D. 1977, Harvard Law School. Financial support for this research was provided by the Marshall D. Ewell Research Fund, IIT Chicago-Kent College of Law. I wish to thank the participants in the American Bar Foundation/Northwestern University Law School Faculty Workshop for their helpful comments on an earlier draft of this paper. I also thank Peter $N$. Clark and Linda Stinauer for their research assistance.

1. UP represents the undisclosed principal, and $A$, the agent. $T$ is referred to as the third party, although $T$ is unquestionably a party to any contract that might exist here between $A$ and $T$. The origin of the convention is that $T$ is a "third party" to the agency relationship of $U P$ and $A$. In this Article, I adopt the conventional terminology, including reference to $U P$ as an "undisclosed" principal both before and after $T$ learns of his existence and identity.

2. H. Reuschlein \& W. GREgory, HandbooK on the Law of Agency and 
caused at least one commentator to deprecate the value of legal theory itself. ${ }^{3}$ Unfortunately, very few, if any, contemporary contract theorists have considered the issue of undisclosed agency at all. ${ }^{4}$

In this Article, I explain the apparent anomaly of the present law of undisclosed agency by applymg modern entitlement theory and a "consent theory of contract." agency is considered to be anomalous by sketching four illustrative cases that conventional theories of contractual obligation cannot explain. To help correct the current dearth of American agency law scholarship, I also provide citations to the most recent state cases on the basic principles of undisclosed agency. ${ }^{6}$ In Part II, I summarize a consent theory of contract and apply it, first to the paradigm case of undisclosed agency described above, and then to several "hard cases." My conclusion is that most current undisclosed agency doctrine is supported by sound modern

PARTNERSHIP § 95, at 159 (1979) ("The rules governing the undisclosed principal have often been described as anomalous."); Müller-Freienfels, The Undisclosed Principal, 16 MoD. L. Rev. 299, 299 (1953) ("No decision and no textbook omits to call it expressly 'an anomaly in the law of contracts' ....”); see, e.g., Ames, Undisclosed Principal-His Rights and Liabilities, 18 Y ALE L.J. 443, 443 (1909) (the doctrine of the undisclosed principal "ignores . . . fundamental legal principles" and "should be recognized as an anomaly"); Goodhart \& Hamson, Undisclosed Principals in Contract, 4 CAMBRIDGE L.J. 320, 356 (1932) ("The undisclosed principal is an anomaly in the sense that he is allowed to sue or be sued although not a party to the contract on which suit is brought . ..."); Higgins, The Equity of the Undisclosed Principal, 28 MOD. L. REV. 167, 167 (1965) ("The doctrinc of the undisclosed principal ... is clearly anomalous in the context of the strict common law rules of contract."); Note, 3 LAw Q. REv. 359 (1887) ("the whole law as to the rights and liabilities of an undisclosed principal is inconsistent with the elementary doctrines of the law of contract."); Schiff, The Undisclosed Principal: An Anomaly in the Laws of Agency and Contract, 88 Coм. L.J. 229 (1983). But cf. Seavey, The Rationale of Agency, 29 Y ALE L.J. 859, 877 (1920) ("I think that the doctrine is not as black or as peculiar as it is painted ....").

3. Hill, Some Problems of the Undisclosed Principal, 1967 J. Bus. L. 122, 124 (footnotes omitted):

The doctrine has been widely criticised as an anomaly which for practical convenience and precedence must be retained. This is largely owing to the fact that the courts havc ignored the jurisprudential aspects of the doctrine, and it seems that the discovery of a basis for the doctrine is not furthered by the many judginents thereon.

It seems, therefore, that further effort to establish the bases of the doctrine will not assist in defining the extent of the limitations thereof.

4. This may result from the current neglect of agency law in the American law school curriculum. See Farber \& Matheson, Beyond Promissory Estoppel: Contract Law and the "Invisible Handshake," 52 U. CHI. L. REV. 903, 917 (1985): "Because agency law has all but disappearcd as a separate legal discipline, attorneys, judges, and law clerks are ill-equipped to perceive agency issues." Perhaps this explains why most of those who have written about the problem recently are British or Canadian.

5. See Barnett, $A$ Consent Theory of Contract, 86 Colum. L. Rev. 269 (1986).

6. I am particularly indebted to Peter N. Clark for the case research presented in Part I. Hc used WESTLAW to search for all the state cases in which a form of the words "undisclosed" or "concealed" appeared in the same sentence as either the word "principal" or "agent." In many of the retrieved cases, the court did not consider the contractual liability arising from an undisclosed agency relationship. The authorities presented infra notes 8-10 were gleaned from the 168 cases in 38 states where this liability was an issue. Where there was more than one case from any given state, I have cited only the most recent one. 
entitlements theory and a consent theory of contract. Moreover, where doctrinal conflict exists among American courts or between American and English courts, a consent theory of contract can be used to determine which stance is preferable. In Part III, I identify the doctrine of assumpsit-a product of promise-based contract theory-as the source of the seeming anomaly of undisclosed agency law. Having thus squared undisclosed agency law with contract theory, I observe in Part IV that the judicial development of this coherent body of doctrine illustrates the proper role of legal theory in the developinent of legal doctrine.

I

\section{The ANomaly of UNDisclosed AgENCY}

\section{A. The Law of Undisclosed Agency}

To see why the law of undisclosed agency is thought to be anoinalous, consider a series of hypothetical illustrations. First, consider the paradigm case:

Illustration 1. $A$ and $T$ manifest to each other assent to a contract for some goods. $A$ bargains for $T$ 's rights to the goods, and $T$ bargains for $A$ 's payment. Unknown to $T, A$ represents $U P$. If $T$ fails to deliver the goods, can $A$ sue $T$ ? Can $U P$ sue $T$ ? If $U P$ fails to pay $T$ for the goods, can $T$ sue $A$ ? Can $T$ sue $U P$ ?

Under conventional contract principles, $A$ is contractually liable to $T$, and $T$ to $A$. Each has "bargamed for" the assent or promise of the other. ${ }^{7}$ Therefore, a failure to pay for or dehiver the goods constitutes a breach of contract and provides the nonbreaching party with a good cause of action against the party im breach. The law of undisclosed agency is in accord. ${ }^{8}$

7. Although I here refer only to a bargain theory of contract, I below examine these relationships under all five standard theories of contract. See infra text accompanying notes 19-38.

8. See Restatement (SECOND) of AGENCY $§ 322$ (1957); see, e.g., Davis v. Childers, 381 So. 2d 200 (Ala. Civ. App. 1979), cert. denied, 381 So. 2d 202 (Ala. 1980); Jensen v. Alaska Valuation Serv., 688 P.2d 161 (Alaska 1984); Mahan v. First Nat'1 Bank of Ariz., 139 Ariz. 138, 677 P.2d 301 (1984); J \& J Builders Supply v. Caffin, 248 Cal. App. 2d 292, 56 Cal. Rptr. 365 (1967); Hott v. Tillotson-Lewis Constr. Co., 682 P.2d 1220 (Colo. Ct. App. 1983); Connecticut Limousine Serv. v. Powers, 7 Conn. App. 398, 508 A.2d 836 (1986); Van D. Costas, Inc. v. Rosenberg, 432 So. 2d 656 (Fla. Dist. Ct. App. 1983); Fisher Scientific Co. v. McCorkle, 163 Ga. App. 613, 295 S.E.2d 366 (1982); McCluskey Commissary, Inc. v. Sullivan, 96 Idaho 91, 524 P.2d 1063 (1974); Vander Wagen Bros. v. Barnes, 15 Ill. App. 3d 550, 304 N.E.2d 663 (1973); Brown v. Owen Litho Serv., 179 Ind. App. 198, 384 N.E.2d 1132 (1979); Amortibanc Inv. Co. v. Rampart Assoc. Management, Inc., 6 Kan. App. 2d 227, 627 P.2d 389 (1981); Grinder v. Bryans Rd. Bldg. \& Supply Co., 290 Md. 687, 432 A.2d 453 (1981); Robert Trent Jones, Inc. v. Canter, 19 Mass. App. Ct. 321, 474 N.E.2d 560 (1985); Paynesville Farmers Union Oil Co. v. Ever Ready Oil Co., 379 N.W.2d 186 (Minn. Ct. App. 1985); David v. Shippy, 684 S.W.2d 586 (Mo. Ct. App. 1985); Como v. Rhines, 198 Mont. 279, 645 P.2d 948 (1982); Community Oil Co. v. Hashem, 106 N.H. 291, 210 A.2d 475 (1965); Tabloid Lithographers, Inc. v. Israel, 87 N.J. Super. 358, 209 A.2d 364 (1965); Van Rossem v. Penney Travel Serv., 128 Misc. 2d 50, 488 N.Y.S.2d 595 (Dist. Ct. 1985); MAS Corp. v. Thompson, 62 N.C. App. 
The conceptual problem arises when we consider UP's liability to $T$ and $T$ 's liability to $U P$. According to normal contract theory, $U P$ is not a party to the contract between $A$ and $T$. $U P$ never manifested his assent to $T ; T$ never manifested her assent to $U P$. It was $A$ who promised to pay for the goods and $T$ who promised to buy them. $A$ kept $U P$ 's existence a secret from $T$. Although the law of contract usually does not permit the secret intentions or knowledge of one party to affect the rights of the other, the normal law of undisclosed agency permits $U P$ to sue $T$ for failure to deliver, ${ }^{9}$ and permits $T$ to sue $U P$ for failure to pay. ${ }^{10}$

Further problems arise in the "hard cases" where $A$ becomes insol-

31, 302 S.E.2d 271 (1983); James G. Smith \& Assoc. v. Everett, 1 Ohio App. 3d 118, 439 N.E.2d 932 (1981); Lane v. Oklahoma-Lincoln, Inc., 583 P.2d 518 (Okla. Ct. App. 1978); Salem Tent \& Awning Co. v. Schmidt, 79 Or. App. 475, 719 P.2d 899, review denied, 302 Or. 36, 726 P.2d 935 (1986); Cooper v. Hileman, 88 S.D. 516, 222 N.W.2d 299 (1974); Wescon, Inc. v. Morgan, 699 S.W.2d 556 (Tenn. Ct. App. 1985); A to Z Rental Center v. Burris, 714 S.W.2d 433 (Tex. Ct. App. 1986); Wilkerson v. Stevens, 16 Utah 2d 173, 397 P.2d 983 (1965); Thomas Branch \& Co. v. Riverside \& Dan River Cotton Mills, 147 Va. 522, 137 S.E. 614 (1927); Maxwell's Elec., Inc. v. Hegeman-Harris Co., 18 Wash. App. 358, 567 P.2d 1149 (1977); S-Creek Ranch, Inc. v. Monier \& Co., 509 P.2d 777 (Wyo. 1973).

9. See, e.g., Wood Building Corp. v. Griffitts, 164 Cal. App. 2d 559, 330 P.2d 847 (1958); Oceanus Mut. Underwriting Assoc. v. Fuentes, 456 So. 2d 1230 (Fla. Dist. Ct. App. 1984), review denied, 466 So. 2d 217 (Fla. 1985); Siplast, Inc. v. Inland Container Corp., 172 Ga. App. 341, 323 S.E.2d 187 (1984); Branham v. Fullmer, 25 Mich. App. 100, 181 N.W.2d 36 (1970); Kivort Steel, Inc. v. Liberty Leather Corp., 110 A.D.2d 950, 487 N.Y.S.2d 877 (1985); Lemon v. Deschutes Valley Farms, Inc., 270 Or. 638, 528 P.2d 1339 (1974); Trustees of Methodist Episcopal Church v. Equitable Sur. Co., 269 Pa. 411, 112 A. 551 (1921). But cf. Heart of America Lumber Co. v. Belovc, 111 F.2d 535 (8th Cir. 1940) (UP cannot sue $T$ where $A$ 's contract with $T$ appcars to state that $A$ is not acting as an agent for an undisclosed principal); Hunter v. Austin Co., 336 So. $2 \mathrm{~d} 203$ (Ala. Civ. App.) (parol evidence cannot be used to prove existence of $U P$ when contract was not ambiguous), cert. denied, 336 So. 2d 208 (Ala. 1976); Cowan v. Curran, 216 111. 598, 75 N.E. 322 (1905) (UP cannot sue $T$ where exclusive credit was given to $A$ ); Kaufman v. Sydeman, 251 Mass. 210, 146 N.E. 365 (1925) (UP cannot sue if $T$ refused to make contract with UP); Arnold's of Miss., Inc. v. Clancy, 251 Miss. 613, 171 So. 2d 152 (1965) (UP cannot sue $T$ when the writing specifically excludes UP from the contraet between $A$ and T); Limb v. Federated Milk Producers Assoc., 23 Utah 2d 222, 461 P.2d 290 (1969) (UP cannot sue $T$ where the contract involved personal trust and confidence in $A$ ).

10. See Restatement (Second) of Agency § 186 (1957); see, e.g., Woods v. Commercial Contractors, Inc., 384 So. 2d 1076 (Ala. 1980); Wahyou v. Kiernan, 145 Cal. App. 2d 443, 302 P.2d 638 (1956); Burnell v. Morrison, 46 Colo. 533, 105 P. 876 (1909); E. M. Workman Co. v. Harrison, 3 Conn. Cir. Ct. 557, 221 A.2d 276 (1966); Bertram Yacht Sales v. West, 209 So. $2 \mathrm{~d} 677$ (Fla. Dist. Ct. App. 1968); Vander Wagen Bros. v. Barnes, 15 11l. App. 3d 550, 304 N.E.2d 663 (1973); Amortibanc Inv. Co. v. Rampart Assoc. Management, Inc., 6 Kan. App. 2d 227, 627 P.2d 389 (1981); Poretta v. Superior Dowel Co., 153 Me. 308, 137 A.2d 361 (1957); Grinder v. Bryans Rd. Bldg. \& Supply Co., 290 Md. 687, 432 A.2d 453 (1981); Rozene v. Sverid, 4 Mass. App. Ct. 461, 351 N.E.2d 541 (1976); Lenart v. Ragsdale, 148 Mich. App. 571, 385 N.W.2d 282 (1986); A. Gay Jenson Farms Co. v. Cargill, Inc., 309 N.W.2d 285 (Minn. 1981); Mountain States Resources, Inc. v. Ehlert, 195 Mont. 496, 636 P.2d 868 (1981); DeBaca, Inc. v. Montoya, 91 N.M. 419, 575 P.2d 603 (1978); Grodsky v. Bernstein, 135 N.Y.S.2d 897 (1954); Wilkerson v. Stevens, 16 Utah 2d 173, 397 P.2d 983 (1965); Maxwell's Elec., Inc. v. Hegeman-Harris Co., 18 Wash. App. 358, 567 P.2d 1149 (1977). But cf. Cartwright v. Giacosa, 216 Tenn. 18, 390 S.W.2d 204 (1965) (parol evidence not permitted to vary terms of contract that on its face shows neither ambiguity nor an undisclosed principal); Sherrill v. Bruce Advertising, Inc., 538 S.W.2d 865 (Tex. Civ. App. 1976) (UP not liable if $T$ had knowledge of 
vent, as shown by the next two illustrations. First, consider the effect of $A$ 's insolvency on $T$ 's rights under the contract:

Illustration 2. Same facts as Illustration 1, except that after $T$ delivers the goods to $A$, who in turn delivers them to $U P, U P$ pays $A$ the money for the goods. $A$ becomes insolvent before paying $T$ for tlie goods. Can $T$ sue $U P$ for payinent?

In Illustration $1, T$ was permitted to sue $U P$ for failure to pay. Yet here, most American courts, stressing the fact that $T$ contracted with $A$ and rehed solely on $A$ 's credit, would deny $T$ a right to sue $U P$ for payment. ${ }^{11}$ In contrast, Enghsh courts would permit $T$ to recover from $U P,{ }^{12}$ forcing $U P$ to pay twice unless $T$ had done solnething to induce $U P$ to settle with A. ${ }^{13}$

Coinpare these results with how $A$ 's imsolvency affects $U P$ 's rights:

Illustration 3. Now $T$ is buying goods from $A$. $U P$, concerned about $A$ 's financial condition, inforns $T$ that he is $A$ 's principal and therefore the "true" seller, and that $T$ sliould pay liim directly for the goods. $T$ pays $A$ anyway. $A$ becomes insolvent and fails to pay $U P$. Can $U P$ sue $T$ for payment?

This was precisely the problem addressed in the early case of Scrimshire v. Alderton. ${ }^{14}$ In Scrimshire, the trial judge directed the jury to find that, where $T$ disregarded $U P$ 's instructions and settled with $A, U P$ could recover the purchase price from $T$, forcing $T$ to pay twice. ${ }^{15}$ American

$U P$ but obtained judgment from $A$ ); Sanger v. Warren, 91 Tex. 472, 44 S.W. 477 (1898) (conveyance of land titles are binding only on signatories).

11. Fradley v. Hyland, 37 F. 49 (C.C.S.D.N.Y. 1888); see Schiff, The Problem of the Undisclosed Principal and How it Affects Agent and Third Party, 1984 DET. C.L. Rev. 47, 66 (noting that courts in most American jurisdictions observe "the rule that an undisclosed principal, otherwise liable on the contracts of his agent, is not liable to a third party when he makes payment in good faith to his agent prior to disclosure to the third party of the principal's existence"); Annot., 71 A.L.R.2d 911, 917 (1960) (majority rule in the United States is that payment to agent discharges an undisclosed principal from liability to third party). Note, however, that some of the more recent American decisions have adopted the English rule as recommended by the RESTATEMENT (SECOND) OF AGENCY $§ 208$ (1957) (described infra note 62).

12. An extensive discussion of the English cases can be found in Poretta v. Superior Dowel Co., 153 Me. 308, 325-26, 137 A.2d 361, 371 (1957). See also Annotation, supra note 11, at 924-26.

13. Throughout this Article, I use the term "to settle" to denote that one party pays money to discharge an account with another.

14. 2 Stra. 1182, 93 Eng. Rep. 1114 (1743). For scholarly commentary on Scrimshire, see Ames, supra note 2, at 446; Müller-Freienfels, supra note 2, at 302; cf. Geva, Authority of Sale and Privity of Contract: The Proprietary Basis of the Right to the Proceeds of Sale at Common Law, 25 MCGILL L.J. 32, 58 (1979) (Scrimshaw was "the first direct contest between the merchant and a buyer with respect to the proceeds of the sale.") (emphasis in original). Geva points out that "previous factor cases were contests between the merchant and assignees in bankruptcy (or creditors) of the factor." Id. at $58 \mathrm{n} .189$.

15. 2 Stra. at 1183,93 Eng. Rep. at 1115 . The case is also famous for the repeated refusals to follow the judge's direction by the original jury as well as by a subsequent special jury. Id.; see also Ames, supra note 2, at 446 . For an analysis that supports the juries' intransigence, see infra text accompanying notes $81-85$. 
courts have accepted this doctrine. ${ }^{16}$

The Scrimshire doctrine contrasts with the rule governing Illustration 2, where American courts would not permit $T$ to recover from $U P$ when UP settled with $A$. Symmetry would seem to require that UP should not be able to recover from $T$ when $T$ has settled with $A$, given that $T$ cannot recover from $U P$ when $U P$ has settled with $A$. Any theory justifying current undisclosed agency law should explain this apparent anomaly.

Finally, consider another hard case:

Illustration 4. Same facts as Illustration 1. After entering into the contract with $A, T$, an archcompetitor of $U P$, learns of $U P$ 's existence and identity and refuses to deliver the goods. May UP or $A$ sue $T$ for breach?

In Illustration 1, the law of undisclosed agency permits $U P$ to sue and be sued as a party to the contract without regard for the secret nature of the relationship between $U P$ and $A .{ }^{17}$ In this case, however, if either $A$ or $U P$ knew of $T$ 's attitude, then most courts would permit $T$ to rescind the contract. $^{18}$

\section{B. Undisclosed Agency and Contract Theory}

How well do the traditional theories or principles of contractual obligation explain these doctrinal results? Elsewhere, I have described the five traditional theories of contract as the will, reliance, efficiency, substantive fairness, and bargain theories. ${ }^{19}$ Here, I argue that none of these theories adequately explains the law of undisclosed agency.

The will theory looks to see if both parties subjectively assented to a contract. $^{20} \mathrm{~A}$ will theory can explain why $T$ would be bound to $A$ in Illustration 1, but it cannot explain $A$ 's liability to $T$, since $A$ was secretly representing $U P$ and may not have intended to be bound personally. Because subjective assent by $T$ to contract with $U P$ is lacking in all four Illustrations, a will theory does not explain the instances where UP can

16. See Restatement (SECOND) OF AgENCY $\$ 310$ and comments (1957); see, e.g., Ricc \& Bullen Malting Co. v. International Bank, 185 Ill. 422, 56 N.E. 1062 (1900); Pitts v. Mower, 18 Me. 361 (1841); Henderson, Hull \& Co. v. McNally, 48 A.D. 134, 62 N.Y.S. 582 (1900), aff'd, 168 N.Y. 646, 61 N.E. 1130 (1901); Lemon v. Deschutes Valley Farms, Inc., 270 Or. 638, 528 P.2d 1339 (1974).

17. See supra notes 9-10 and accompanying text.

18. H. REUSCHLEIN \& W. GRegory, supra note 2, $\$ 107$, at 173 ("The cases are all but unanimous in allowing rescission where the principal or the agent knows that the other party would not enter into the contract with the principal, but fails to disclose that fact thus perpetrating a fraud."); see, e.g., Daniel Boone Complex, Inc. v. Furst, 43 N.C. App. 95, 258 S.E.2d 379 (1979); Cummings v. Jorgensen, 25 Utah 2d 274, 480 P.2d 466 (1971).

19. See Barnett, supra note 5, at 271-91 (describing these five theories and their inherent deficiencies). When these concepts are combined within a theory of contractual obligation, they are better characterized as principles or "core concerns" rather than theories.

20. See id. at 272-74 (describing a will theory of contract and its deficiencies). 
sue $T$. Moreover, in Illustration 4, $T$ may escape liability by objecting to $U P$ as a contracting party, but only if $U P$ or $A$ was aware of $T$ 's unwillingness to contract with $U P .^{21}$ This result lends no credence to a subjective will theory.

Even if we limit our inquiry, as most inodern analysts would, to the presence of objective or manifested assent, ${ }^{22}$ we find no manifestation of assent by $T$ to contract with $U P$. Nor lias $U P$ inanifested assent directly to $T$, except vicariously, and in a disguised manner, through $A$.

The seeming incongruity between the law of undisclosed agency and theories of contract based on either subjective or objective assent is probably the main reason that the doctrine of undisclosed agency historically has been considered anomalous. This comment froin the Restatement (Second) of Agency is representative:

The rules with reference to undisclosed principals appear to violate one of the basic theories of contracts. The relation between the principal and a person with whom the agent has made an authorized contract is spoken of as contractual, although by definition there has been no manifestation of consent by the third person to the principal or by the principal to him. In fact, the contract, in the common law sense, is between the agent and the third person. In spite of this, the law of agency finds it expedient to create rights and habilities between the other party to the transaction and the principal as if the latter were a contracting party. ${ }^{23}$

The second traditional contract theory, the reliance theory, which looks to the existence of "reasonable" and detrimental reliance, ${ }^{24}$ fares little better. If $T$ does not know of $U P$ 's existence, she can never rely on $U P$ 's commitment. Therefore, a reliance theory cannot explain why $T$ may hold $U P$ liable as a party to the contract. Frederick Pollock, an early and persistent critic of the doctrine of undisclosed agency, made a similar observation:

$A$ enters into the service of $X$, he does not know of the existence of $Y$ and $Z, X$ 's dorinant partners. It therefore follows that he was induced to enter into the contract by his trust in the promise of $X$ to remunerate him; and if he afterwards discovered that $X$ had no partners, $A$ would have no reason to complain. Why then should he gain by the fact, which

21. See RESTATEMENT (SECOND) OF AGENCX § 304 \& comment a (1957); see, e.g., Akwell Corp. v. Eiger, 141 F. Supp. 19, 22 (S.D.N.Y. 1956) (where no evidence that $T$ previously refused to contract with principal, his later statement that he would not have entered into the contract had he known the UP is no defense); Hunter Tract Improvement Co. v. Stone, 58 Wash. 661, 109 P. 112 (1910) (where neither UP, who was black, nor his agent knew or had reason to know that $T$ would not have sold property to a black, a subsequent claim of such unwillingness did not support a defense of mistake).

22. See, e.g., E. FARNSWORTH, CONTRACTS 113-14 (1982).

23. RESTATEMENT (SECOND) OF AGENCY $§ 186$ comment a (1957); see also authorities cited supra note 2.

24. See Barnett, supra note 5 , at 274-77 (describing a reliance theory of contract and its deficiencies). 
never influenced his conduct, that $Y$ and $Z$ were $X$ 's partners when $A$ contracted with $X{ }^{25}$

Since UP's liability is a central tenet of undisclosed agency law, a reliance theory has serious explanatory shortcomings. Furthermore, a reliance theory may not explain $T$ 's liability to $A$ in Illustration 1 , since it is not clear how $A$, acting solely on $U P$ 's behalf, would have detrimentally rehed on $T$. The only relations a reliance theory might explain are: (1) $T$ 's liability to $U P$ in Illustration 1 , if $U P$ knew of and relied on $T$ 's commitment, and (2) $A$ 's obligation in Illustration 1, if $T$ can be shown to have relied on $A$ 's promise.

Both the efficiency and substantive fairness theories, the third and fourth traditional contract theories we consider, are standards-based. A standards-based theory evaluates the results of the transactions against a predetermined standard regarded as primary. ${ }^{26}$ There are two iminediate probleins with such theories. First, they require a mechanism for discovering and justifying the standards they apply. Second, they would not enforce any transaction that failed to meet the proper standard, even one im which the parties are in inutual agreement. ${ }^{27}$

I discuss elsewhere why an efficiency analysis cannot by itself produce a normative assessment of contractual obligation. ${ }^{28}$ Moreover, if a consent theory of contract is consistent with or even necessary to achieving allocational efficiency, ${ }^{29}$ then the outcomes it specifies in the area of undisclosed agency are likely to facilitate efficiency without resorting to an exphicit efficiency analysis. Still, economic analysis can tell us much of miportance about agency relationships. ${ }^{30}$ Although to my knowledge economists have yet to discuss specifically the problems uinque to undisclosed agency, enforcing contracts made on behalf of undisclosed principals provides important economic benefits. Permitting principals to conceal their existence is one way to overcoine strategic behavior-or socalled "hold-out" problems-that can impair the fornation of mutually beneficial contracts. Many buyers seek to avoid having to pay more for a

25. Note, 14 LAW Q. REv. 5 (1898) (emphasis added).

26. See Barnett, supra note 5 , at $277-86$.

27. Id. at 285-86.

28. See id. at $277-83$.

29. See id.

30. Thus far, however, economic analysis has been applied to "agency cost" questions largely to explain the existence of "the firm." These analysts ask why and when it is rational or efficient to separate "ownership" (the beneficial residual claim to the firm's cash flow) from "control" (the decisionmaking power to allocate the firm's resources). See generally Fama, Agency Problems and the Theory of the Firm, 88 J. PoL. ECON. 288 (1980); Fama \& Jensen, Separation of Ownership and Control, 26 J.L. \& Econ. 301 (1983); Fama \& Jensen, Agency Problems and Residual Claims, 26 J.L. \& EcoN. 327 (1983); Jensen \& Meckling, Theory of the Firm: Managerial Behavior, Agency Costs and Ownership Structure, 3 J. Fin. EcoN. 305 (1976).

Recently, some economists have begun to broaden this analysis. See, e.g., Principals AND Agents: The Structure of Business (J. Pratt \& R. Zeckhauser eds. 1985). 
particular item solely because the seller knows of the buyer's deep pocket. ${ }^{31}$ For example, im Serior v. Bangor Mills, Inc., ${ }^{32}$ the defendant, a prodigious user of nylon yarn, had to make frequent and substantial purchases in the "secondary" market in order to maintain its production levels. Because its needs and economic position were well known, it was asked to pay prices that were very high even for that market. Accordingly, it sought to buy yarn more cheaply through an intermediary. ${ }^{33}$

In addition to the problems inentioned above, since there is nothing in any of the illustrations to indicate the substantive "unfairness" of the exchange, a substantive fairness theory ${ }^{34}$ has nothing whatsoever to say about how these cases should be decided. ${ }^{35}$

The final traditional theory, the bargain theory of contract, ${ }^{36}$ only explains $A$ and $T$ 's liability to each other. Where $U P$ did not himself bargain with $T$ and $T$ certainly did not knowingly bargain with $U P$, it is unclear under the bargain theory why $U P$ or $T$ would be liable to each other. The inability of the five best known theories of contractual obligation to explain the seemingly anomalous results of the law of undisclosed agency is symptomatic of the general weakness of each of these five approaches standing alone.

Moving beyond the purview of contract theory, a noncontractual, restitution-based "unjust enrichınent" analysis is deficient as well. Sometimes $U P$ is enriched at $T$ 's expense, and sometimes (as in Illustration 2) he is not. UP's liability does not usually turn on this fact. "Enrichinent" normally refers to the receipt by a person of benefits not paid for. Therefore, when $U P$ is enriched, $A$ is surely not. Yet $A$ nonetheless remains subject to liability until $T$ elects to pursue $U P$. Moreover, $T$ 's liability in Illustration 3 camiot be justified in terms of restitution, since $T$ has already paid for the goods once.

Although the law of undisclosed agency has lacked adequate theoretical justification, it makes some sense intuitively ${ }^{37}$ If this body of rules

31. Situations where a consent theory would permit a third party to rescind a contract upon discovering the identity of the principal are discussed infra text accompanying notes 86-100.

32. 211 F.2d 685 (3d Cir. 1954).

33. Id. at 687. There is an irony here for unconscionability theory in that the perception of the defendant's large requirements and wealth undermined rather than enhanced its bargaining position, if not its "power."

34. See Barnett, supra note 5, at $283-85$ (describing a substantive fairness theory of contract and its deficiencies).

35. Cf. id. at 285 (" $[t]$ he substantive fairness approach fails to address squarely the most central and common problem of contract theory: which conscionable agreements should be enforced and which should not?") (emphasis in original).

36. See id. at 287-89 (describing and criticizing a bargain theory of contract and its deficiencies).

37. Cf. H. ReuSCHLEIN \& W. GREGORY, supra note 2, $\S 95$, at 159-60 ("It seems significant to note that the commercial fraternity, which has been so active in seeking uniform legislation in other 
can be theoretically justified, it will reaffirm an important virtue of a common law system: that the process of adjudicating countless cases can lead judges uninformed by the niceties of legal theory (or despite their familiarity with legal theory) to a more just body of rules. ${ }^{38}$ Legal theory, however, is still necessary to shape the doctrines that result from common law adjudication and to assist judges in deciding hard cases. Legal theory is also needed to justify the spontaneously evolved doctrines. For these reasons, Part II critically apphies a consent theory of contract to the law of undisclosed agency.

\section{II}

\section{Undisclosed Agency in a Consent Theory of CONTRACT}

\section{A. A Consent Theory of Contract}

Although a consent theory of contract is more fully expounded elsewhere, ${ }^{39}$ I should give a brief summary of it here before applying it to the law of undisclosed agency. A consent theory of contract is part of a more comprehensive, proprietary conception of legal entitlements. This conception construes legal rights as enforceable claims to acquire, use, and transfer resources-claims to control one's person and external resources. ${ }^{40}$ Because contracts serve to transfer control of certain resources, contract law should be grounded in a theory that explains why people have and can control those resources in the first place. Contract theory searches for the "other factors" that transform an unenforceable promise or stateinent of intention into a legally enforceable contract. ${ }^{41}$ A consent theory of contract requires that an enforceable contract satisfy at least two conditions. First, the subject of a contract must be a morally cognizable right possessed by the transferor that is mterpersonally transferable, or "alienable." Second, the possessor of the alienable right must

areas affecting business, has registered no serious complaints. This would seem to indicate that the rules are at least reasonably satisfactory to the coinunercial world.").

38. See 2 K. ZWEIGERT \& H. KöTZ, AN InTROduction to COMPaRATIVE LAW 104 (1977) ("Although eminent English and American jurists have thought of this rule as an anomaly of the Common Law, it is regarded by continental lawyers as a forward-looking doctrine which could serve as a landınark for legal development."); $c f$. Müller-Freienfels, Comparative Aspects of Undisclosed Agency, 18 MOD. L. REV. 33, 41 (1955) ("Both laws admit, starting froin opposed principles so many exceptions that . . . both extensively accord in practical results."). See generally 1 F. A. HAYEK, LAW, LEGISLATION, AND LIBERTY (1973) (describing the evolutionary process produced by adjudication). I will return to this theine infra text accompanying notes 140-45.

39. The summary of a consent theory of contract presented here is necessarily a truncated one. The theory is presented in greater length in Barnett, supra note 5, at 291-321, and Barnett, Contract Remedies and Inalienable Rights, 4 Soc. PHIL. \& PoL'Y, Autumn 1986, at 179.

40: See Barnett, supra note 5, at 291-300; Barnett, Pursuing Justice in a Free Society: Part One-Power vs. Liberty, CRIM. Just. ETHICs, Summer/Fall 1985, at 50.

41. 1 A. CoRbin, CoRbIN on CoNTracts \$ 110, at 490-94 (1963); see also Eisenberg, The Principles of Consideration, 67 CORNELL L. REV. 640 (1982). 
manifest his intention to be legally bound to transfer the right-that is, he must consent. ${ }^{42}$ In a consent theory, neither consideration nor reliance are essential to contract formation. ${ }^{43}$

In the vast majority of contracts cases, the vexing issue is neither the alienability of rights nor even whether the parties manifested consent to transfer rights. Most "real-world" contractual disputes involve determining precisely which rights were intended to be transferred by the parties. ${ }^{44}$ But a close examination of either the ahenability or the consent requirement can explain the persistent "hard cases" for traditional contract theories. For example, a close analysis of the consent requirement can explain both the justification for enforcing formal agreements that lack bargained-for consideration and the willingness of courts to focus on objective assent in some cases and subjective assent in others. ${ }^{45}$ Similarly, the requirennent of alienability can explam the reluctance of common law courts to specifically enforce personal service contracts. ${ }^{46}$ The supposed "anomaly" of undisclosed agency is another important example of the explanatory value of a consent theory of contract.

\section{B. Explaining the Paradigm Case of Undisclosed Agency}

The paradigm case of undisclosed agency is Illustration 1 . None of the prevailing theories of contractual obligation can satisfactorily explain why $U P$ may either sue or be sued by $T$. Before we address the "hard cases" of contractual obligation posed by Illustrations 2, 3, and 4 (and others as well), we must first consider at length the obligations arising in the paradigm case. Let us recall Illustration 1:

Illustration 1. $A$ and $T$ manifest to each other assent to a contract for some goods. $A$ bargains for $T$ 's rights to the goods, and $T$ bargains for $A$ 's payment. Unknown to $T, A$ represents $U P$. If $T$ fails to dehiver the goods, can $A$ sue $T$ ? Can $U P$ sue $T$ ? If $U P$ fails to pay $T$ for the goods, can $T$ sue $A$ ? Can $T$ sue $U P$ ?

Answermg these questions will require a multifaceted application of a consent theory of contract. We must isolate and consider separately all three legal relationships at issue: (1) the relationship between $A$ and $T$;

42. See Barnett, supra note 5, at 296-300.

43. This aspect of a consent theory also yields a comprehensive explanation of the doctrine of promissory estoppel. See Barnett \& Becker, Beyond Reliance: Promissory Estoppel, Contract Formalities and Misrepresentation, 15 HOFSTRA L. REV. 445 (1987).

44. For this reason, contract theory does not always directly address important problems of interest to doctrinal scholars. See, e.g., Farnsworth, $A$ Fable and $A$ Quiz on Contracts, 37 J. LEGAL Educ. 206, 209 (1987) (noting that decisions concerning energy disputes "have been largely concerned with problems that arise during the performance stage of contracts and have had little occasion to question why promises are enforced"). Nevertheless, I believe that contract theory can help resolve such practical problems.

45. See Barnett, supra note 5, at 300-12.

46. See Barnett, supra note 39, at 197-98. 
(2) the relationship between $A$ and $U P$; and (3) the relationship between $U P$ and $T$.

\section{The Relationship Between the Agent and the Third Party}

When considered apart from the hability of the undisclosed principal, there has never been a problem finding a contractual relationship between the agent and third party. In Illustration 1, $A$ manifests to $T$ his assent to transfer ahenable rights to some goods, and $T$ manifests to $A$ her assent to transfer alienable rights to an amount of money. In a consent theory, the existence of a prima facie binding obligation is unaffected by any "subjective" reservations-that is, reservations of one party that are unexpressed or unknown to the other. ${ }^{47}$ So, despite any relationship that exists between $A$ and $U P$, if $T$ is unaware of this relationship at the time of formation and $U P$ fails to perform, $T$ may still hold $A$ to the contract, ${ }^{48}$ and $A$ may, of course, hold $T$ to the contract as well.

In a consent theory, therefore, the contractual relationship between $A$ and $T$ is as straightforward as it is in standard contract doctrine. ${ }^{49}$ For a contract to exist between $A$ and $T, A$ and $T$ need not have reached a subjective "meetmg of the minds," and $A$ need not have detrimentally rehed upon $T$ 's commitment or received any benefit from $T$.

\section{The Relationship Between the Agent and the Undisclosed Principal}

Curiously, the key to understanding the problematic relationship between the third party and the undisclosed principal lies in a better understanding of the legal relationship between undisclosed principals and their agents. The undisclosed agency relationship between $A$ and $U P$ does not differ from that of the "normal" agency relationship in which the existence or identity of the principal is disclosed to third parties. Agency is a consensual relationship; it is "the fiduciary relation which results from the manifestation of consent by one person to another that

47. The presumption is in favor of the generalized, objective meaning of a term. However, if the promisor can prove that the promisee understood and relied on a subjective, extraordinary meaning of a term, a court may enforce that subjective meaning. Furthermore, a special meaning held in common by the parties is also enforceable. See Barnett, supra note 5, at 307.09.

48. Cf. Ashe v. Vaughan, 159 Okla. 32, 33, 14 P.2d 231, 231 (1932) (quoting Calman v. Kreipke, 40 Okla. 516, 518, 139 P. 698, 699 (1914)): "Although an agent enters into a contract with the actual intention of binding his principal only, if his wording of the same or the circumstance of the case are such as to bind himself, he will be personally liable thereon."

By the same token, in Illustration 4, any mental reservation subjectively held by $T$ concerning a legal relationship between $A$ and $U P$, unexpressed or unknown to $A$ at the time of formation, would not ordinarily affect $A$ 's right to enforce the agreement against $T$. See infra text accompanying notes 86-100.

49. "Standard doctriue" refers to well-settled contract rules and principles. The diverse contract theories discussed above purport to explain the doctrine. See supra text accompanying notes $19-38$. 
the other shall act on his behalf and subject to his control, and consent by the other so to act." 50

In its conception of the agency relationship, however, a consent theory differs from conventional agency theory. Conventional agency theory relies on existing contract doctrine that requires "bargained-for" consideration. Consequently, it recognizes a contract between the principal and agent only when, as in most commercial agency arrangements, the principal commits to compensate the agent for his services. When the relationship is gratuitous and revocable by either party, however, standard agency theory must resort to noncontractual "empowering" of agents. ${ }^{51}$

In contrast, a consent theory contemplates that all agents who are empowered to enter into contracts ${ }^{52}$ with third parties on behalf of their principals also enter into a contract with their principals-a contract in which they exphicitly or implicitly commit to transfer to their principals any rights they receive under the contracts they enter into in their own name but on the principal's behalf. A consent theory identifies any consensual transfer of rights as "contractual," and therefore characterizes the agent's rights-transfer commitment to the principal as contractual, regardless of the presence or absence of consideration. When the normal agent-principal relationship is seen as contractual, it provides a vital "missing link" in a proper understanding of the obligations arising in undisclosed agency situations.

In a normal agency arrangement, an agent contracts with a third party to transfer rights to resources that he, the agent, does not own. A principal who authorizes his agent to so act "on his behalf" consensually empowers the agent to exercise certain rights that the primcipal alone would normally exercise. The right to sell one's goods-for example, one's car-is one aspect of the "bundle of rights" that constitutes "ownership" of goods. It is a right that a lessee of goods, for exainple, does not enjoy. When a principal-owner consensually authorizes an agent to sell his car, he empowers the agent to exercise this right for the benefit of ("on behalf of"), and subject to the control of, the principal-owner. In turn, the agent consensually commits himself to transfer to the principal the rights to the purchase money he acquires from a third party purchaser. ${ }^{53}$

50. RESTATEMENT (SECOND) OF AGENCY $§ 1$ (1957).

51. See Restatement (SECOND) OF AGENCY $\& 6$ (1957) ("A power is an ability on the part of a person to produce a change in a given legal relation by doing or not doing a given act.").

52. The analysis in the text is not intended, therefore, to apply to situations where agents are empowered to perform other, noncontractual kinds of acts on behalf of principals.

53. While each party to this kind of agency relationship necessarily makes a commitment to the other, these "reciprocal" commitments need not constitute traditional "bargained-for" consideration. Though reciprocal, the agent's commitment might be entirely gratuitous. An agent may commit to transfer rights to the purchase money without any intention that this commitment 
The normal results of this consensual agreement ${ }^{54}$ between agent and principal, then, are: (1) the principal grants to the agent the power to alienate the principal's rights to the car; (2) the agent, by exercising this power, effectuates the transfer of all the principal's rights to the car directly from the principal to the third party purchaser; and (3) the agent is consensually committed (to the principal) to transfer to the principal the rights to the purchase money he receives from a third person. Therefore, these rights pass immediately to the principal without any further assent or act by the agent. Nothing in the normal undisclosed agency situation changes this general agency analysis.

The result of this arrangement can be represented as a triangular flow of rights, as illustrated in Figure 1. The undisclosed principal grants the agent the power to sell the car, and then, upon the exercise of this power by the agent, transfers all his rights to the car directly to the third party. The third party transfers the rights to the purchase money to the agent who, by prior contractual agreement, has consented to these rights moving immediately and automatically to the primcipal. To put it more simply, rights flow directly from $U P$ to $T$ and indirectly from $T$ to $U P$ through $A$.

Figure 1

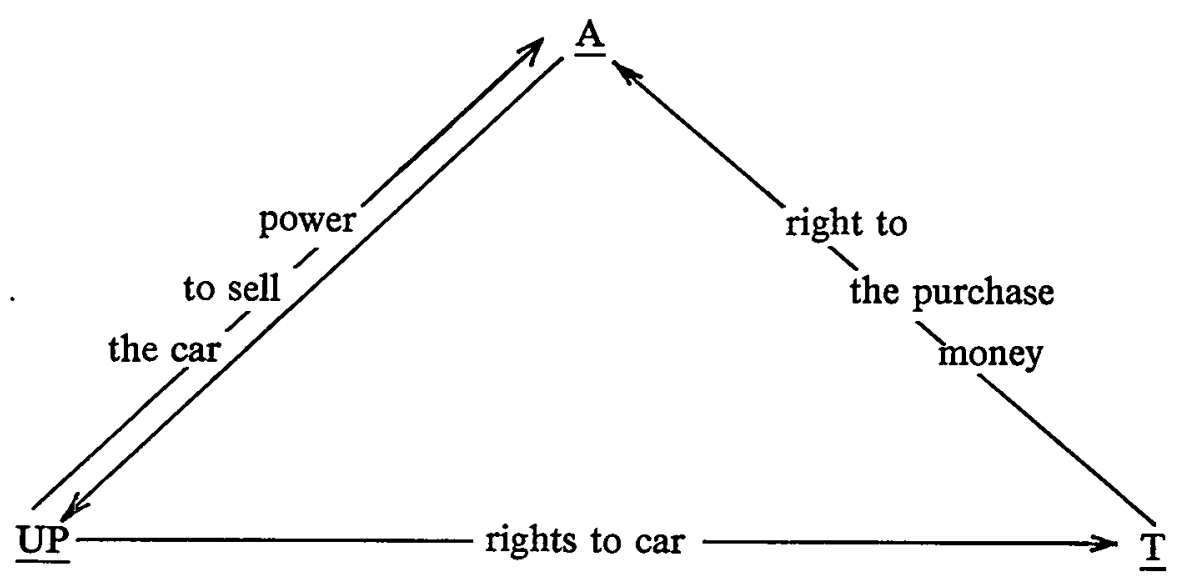

The flow of rights between $U P$ and $A$ is normally the same when, as in Illustration $1, U P$ is buying goods from $T$. In this case, $U P$ grants to $A$

induce the principal to grant him the power to sell the goods. On the other hand, an agent may make this commitment, and others as well, with the intention that it induce the principal to compensate the agent, in which case the agency would not be gratuitous. Traditional agency theory based on traditional contract doctrine recognizes only the latter situation to be "contractual."

54. For other constructions of this arrangement, see infra note 81 and accompanying text. 
the power to transfer ownership of the purchase money to $T$, and $A$ consents to transfer the rights to the purchased goods he acquires from $T$ to $U P$. Once $A$ exercises his power to buy, the rights to the money itself normally flows directly from $U P$ to $T$.

\section{The Relationship Between the Undisclosed Principal and the Third Party}

We are now im a position to assess the relationship between undisclosed principals and third parties. The simultaneous operation of the two distinct contracts between $U P$ and $A$ and between $A$ and $T$ creates a triangular flow of rights. Rights flow from $U P$ directly to $T$, and rights flow indirectly from $T$ to $U P$ through $A$. Whether or not a third contract is said to exist between $U P$ and $T$ is academic. The rights that each has against the other are "contractual" in nature insofar as their distribution resulted from the consensual alienation of proprietary entitlements. This consensual flow of rights redistributes the resource or property rights of the parties, thereby resulting in a cause of action when actual resource holdings fail to correspond to the new set of entitlements.

In Figure 1, where $U P$ has transferred to $T$ all rights to the car, $U P$ 's failure to deliver the car to $T$ would result in an unjust distribution of holdings that ouglit to be corrected. Because holdings must matcli entitlements, a consent theory of contract makes sense of this situation. While the flow of rights to $T$ was initiated by UP's agency relationship with $A$, the effect of $A$ 's exercise of his power to alienate UP's rights is that $T$ now has the right to the car. Thus, $U P$ is wrongfully in possession. Moreover, $A$ is also consensually liable for $U P$ 's failure to perform. $A$ manifested his intention to perform or pay danages, ${ }^{55}$ and is therefore a party to a valid sales contract with $T$. $T$ is then entitled to pursue botll $A$ and $U P$ until she receives either performance or damages. ${ }^{56}$

Now suppose instead that $T$ refuses to pay for the car. Since the sales contract between $T$ and $A$ transfers the riglit to the inoney from $T$ to $A$, and the agency contract between $A$ and $U P$ automatically and inmediately transfers this riglit from $A$ to $U P, U P$ may either sue $T$ directly or authorize $A$ to sue $T$ for payment on his behalf. Nothing in

55. Cases where $A$ has committed to personal performance of the obligation are discussed below as among the "hard cases" of undisclosed agency. See infra text accompanying notes 101-106.

56. The subject of election is beyond the scope of this Article. See RESTATEMENT (SECOND) OF AGENCY \$209-211 (1957); Richmond, Scraping Some Moss From the Old Oaken Doctrine: Election Between Undisclosed Principals and Agents and Discovery of Their Net Worth, 66 MARQ. L. REV. 745 (1983). One recent decision may indicate the future direction of the doctrine of election. See Grinder v. Bryans Rd. Bldg. \& Supply Co., 290 Md. 687, 707-08, 432 A.2d 453, 464 (1981) ("We hold that a creditor who contracts with the agent for an undisclosed principal does not obtain alternative liability, that he may proceed to judgment against both, but that he is limited to one satisfaction."). 
this triangular flow is necessarily affected by $T$ 's ignorance of UP's existence. ${ }^{57}$ The same result would obtain in Illustration 1 if $T$ refused to convey the promised goods.

\section{Explaining the "Hard Cases" of Undisclosed Agency}

A consent theory's account of the paradigm case of undisclosed agency provides a better understanding of the hard cases described in Illustrations 2,3 , and 4 , and others as well.

\section{The Effects of Default by the Agent \\ a. Effect of Settlement With Agent by Principal}

Illustration 2. $T$ delivers the goods to $A$, who in turn delivers them to $U P$. UP pays $A$ the money for the goods, but $A$ becomes insolvent before paying $T$ for the goods. Can $T$ sue UP for payment?

When $U P$ pays the purchase price to $A$, and $A$ becoines insolvent and does not transmit the money to $T$, both $U P$ and $T$ are innocent parties. (This is also true when $T$ pays $A$ for goods purchased from UP, but $A$ becoines insolvent before paying $U P$.) This is a "hard case" for the law of undisclosed agency because one of two innocent parties must bear the loss caused by $A$ 's insolvency. ${ }^{58}$ Because there is no obvious way that the burden of such a loss should be allocated, it is not surprising that American and Enghish courts differ in their treatment of such cases. ${ }^{59}$ What treatinent does a consent theory suggest?

In section $\mathrm{B}, \mathrm{I}$ traced the triangular consensual flow of rights normally created by the two contracts that coinprise an undisclosed agency situation. In Figure 1, UP acquires $T$ 's rights to the car through $A . T$ acquires rights to the purchase inoney directly from $U P$ as a result of $A$ 's exercise of the power granted to him by UP. T's ignorance of UP's existence is normally ${ }^{60}$ inmaterial to this flow of rights, and is therefore mimaterial both to $T$ 's rights against $U P$ and to $U P$ 's rights against $T$.

The flow of rights that explains the paradigm case suggests that in this case $U P$ cannot avoid liability to $T$ simply by giving the purchase inoney to $A$. $U P$ is the real debtor here and he owes the purchase money

57. See RESTATEMENT (SECOND) OF AgeNCY § 195A (1957). Therefore, while T's ignorance of UP's existence can affect the flow of rights in special circumstances, see infra text accompanying notes 86-100, I argue that it need not do so.

58. Cf. Note, The Liability of an Undisclosed Principal After Settlement with the Agent, 18 Miss. L.J. 436, 437 (1947):

Under these conditions, when the rule [imposing liability] is applied without reservation, it results in the principal paying twice on the contract. On the other hand, if the rule is not applied, and the third party cannot enforce his claim against the agent for some reason, such as the agent's insolvency, the third party is left without a remedy.

59. See supra notes 11-13 and accompanying text.

60. But see infra text accompanying notes $86-100$. 
to $T$ and not to $A$. One cannot normally satisfy a debt to a creditor by making payment to a third party without the creditor's consent. ${ }^{61}$ In this situation, $T$ 's ignorance of $U P$ 's existence is relevant. $T$ certainly did not expressly consent to UP's satisfying his debt by paying $A$, and because $T$ was completely ignorant of UP's existence, her consent cannot be implied. Without the express or implied consent of $T$, the rights to the purchase money that $T$ acquires from $U P$ entitle $T$ to payment from $U P$. $U P$ may attempt to satisfy this debt by transmitting the money to $T$ through $A$ (or, for that matter, througli the Post Office), but $U P$ properly bears the risk of loss created by this clioice. UP bears the loss not merely because he chose $A$, but because the flow of rights transferred the right to the money from $U P$ directly to $T$. A consent tlieory would therefore support the Englisli rule that protects third parties-the rule also favored by the authors of the Restatement (Second) of Agency. ${ }^{62}$ A consent theory would reject tlie American rule, which holds that third parties bear the risk of $A$ 's default. ${ }^{63}$

\section{b. Effect of Settlement with Agent by Third Party}

Illustration 3. Now $T$ is buying goods from $A$. UP becomes concerned about $A$ 's financial condition and informs $T$ that he is $A$ 's principal and therefore the "true" seller, and that $T$ should pay him directly for the goods. $T$ pays $A$ anyway. $A$ becomes insolvent. Can $U P$ sue $T$ for payment?

The flow of riglits tliat has occurred here is essentially tlie same as tliat in Illustration 2. While $U P$ acquires the riglits to the purchase money indirectly througlı $A$, those rights entitle him to payment from $T$. When $T$ pays $A$ and $A$ becomes imsolvent, we again must allocate tlie risk of loss between two innocent parties. Despite tlie similarity in tlie flow of rights, lowever, the situation im Illustration 3 is quite different from tliat in Illustration 2.

61. See 60 AM. Jur. 2D Payment $\$ 72$ (1972). Notice that the language of debt (and detinue) is more apt here than the language of assumpsit. See infra text accompanying notes 131-39.

62. See Restatement (Second) of Agency \$ 208 (1957):

An undisclosed principal is not discharged from liability to the other party to a transaction conducted by an agent by payment to, or settlement of accounts with, the agent, unless he does so in reasonable reliance upon conduct of the other party which is not induced by the agent's misrepresentations and which indicates that the agent has settled the account.

See also Poretta v. Superior Dowel Co., 153 Me. 308, 137 A.2d 361 (1957) (adopting $\S 208$ of first Restatement); A. Gay Jenson Farms Co. v. Cargill, Inc., 309 N.W.2d 285 (Minn. 1981) (adopting $\$ 208$ ); Annot., supra note 11 , at $920-22$ (collecting cases following minority rule that payment alone does not discharge principle); $c f$. , Shasta Livestock Auction Yard, Inc. v. Bill Evans Cattle Management Corp., 375 F. Supp. 1027, 1032 (D. Idaho 1974) (implying that an Idaho court would follow the "more modern view" expressed in $\$ 208$ ).

63. This result occurs because most American courts emphasize that $T$ relied on $A$ 's credit alone, not UP's. The American rule, therefore, reflects a reliance theory. See supra text accompanying notes 24-25. 
A creditor may always consent to receive payment through an agent and can consent to assume the risk of loss during transmission. In Illustration $3, U P$ has chosen to deal with $T$ through $A$. If $U P$ does not disclose his existence, $U P$ must bear the loss caused by $A$ 's insolvency. By $U P$ 's choice, the contract with $T$ was entered into on his behalf by $A$. Any such contract would have stipulated that $A$ was to receive payment, simce any other term presumably would disclose the existence of $U P .^{64}$ Because UP expressly consented to receiving payment through $A$, a consent theory provides that $T$ is within her contractual rights to pay $A .^{65}$ In contrast, in Illustration $2, T$ manifested no consent to receive paynent through an agent, and in hight of $U P$ 's secret existence, her consent could not be implied. ${ }^{66}$ This result is harmonious with standard agency law.

Analogously, it is standard contract doctrine that when one party uses a particular inode of communication to tender an offer, it is reasonable for the other party to utilize the same mode to tender acceptance. ${ }^{67}$ In addition, the "mailbox rule" specifies that acceptance is effective upon dispatch - that is, "as soon as put out of the offeree's possession, without regard to whether it ever reaches the offeror."68 The mailbox rule ensures that the offeree can judge when a contract has been formed, while protecting the offeror by empowering him to either choose the manner of acceptance or to specify in the offer that acceptance is effective only upon receipt. Similarly, in the undisclosed agency situation, the principal may protect himself in the original agreement by stipulating the manner of payment. Where the agreement is silent, however, the third party is entitled to rely on the appearances created by the principal, and may pay the agent. As with the mailbox rule, payinent is effective when it is out of the third party's possession.

Illustration 3 asks, however, what the effect is when $U P$ instructs $T$ to make the payment directly to UP. Agency law normally permits any principal, including an undisclosed principal, to opt for direct payment after the contract with a third party is formed. ${ }^{69}$ Such a rule is entirely consistent with the law governing the assignment of contract rights. ${ }^{70}$ Normal contract law creates a presumption ${ }^{71}$ that, in the absence of an

64. UP might have preserved his secret existence by stipulating that payment would be made to $A$ 's agent or to another agent of UP. If so, this stipulation would then determine whom $T$ must pay.

65. See, e.g., Belfield v. National Supply Co., 189 Pa. 189, 42 A. 131 (1899).

66. $T$, of course, did agree to receive payment from $A$, but not through $A$ as an agent.

67. See Restatement (SECOND) OF Contracts § 65 (1979) ("Unless circumstances known to the offeree indicate otherwise, a medium of acceptance is reasonable if it is the one used by the offeror or one customary in similar transactions at the time and place the offer is received.").

68. REstatement (SECOND) OF CONTRACTS $\$$ 63(a) (1979).

69. RESTATEMENT (SECOND) OF AGENCY \& 310 (1957).

70. Cf. Goodhart \& Hamson, supra note 2, at 352 ("The doctrine of the undisclosed principal is perhaps best considered as a primitive and highly restricted form of assignment ....").

71. Developing a consent theory's approach to construing contractual intent when parties are 
expressed term to the contrary, ${ }^{72}$ any contractual right may be assigned to another, provided that this assignment does not materially affect the rights of the obligor. ${ }^{73}$ Normal contract doctrime further states tlrat a change in the identity of the person who is to receive a money payment will not ordinarily be considered material. ${ }^{74}$

Agency law simply apples this rule to the contract between $T$ and $A$ by interpretimg the rights received by $U P$ from $T$ via $A$ as though they were rights assigned by $A$ to $U P .{ }^{75}$ Similarly, the "flow of rights" analy-

silent on an issue would require a lengthy and separate treatment. Such an effort would involve, among other topics: (1) a discussion of tacit versus expressed knowledge; (2) the presumption that the parties intended what most similarly situated parties would have intended ex ante, thus putting the onus on a minority of parties to express their dissent from the majority by an express term; and (3) the likely incentive effects of the principles of construction on the bargaining behavior of other parties. For an analysis that uses the last of these factors, see Barnett, supra note 39, at 198-201 (discussing the incentive effects of the presumption that limits the remedy for breach of contract to monetary damages).

72. But see U.C.C. \$9-318(4) (1977) ("A term in any contract between an account debtor and an assignor is ineffeetive if it prohibits assignment of an account ...."). The official comment to this section cites "economic need" to justify this rule which "breaks sharply with the older contract doctrines." U.C.C. \& 9-318(4) coinment 4 (1977). The comment somewhat sarcastically concludes that this change can be regarded as a radical departure only by those "who still cherish the hope that we may yet return to the views entertained some two hundred years ago by the Court of King's Bench." Id.

Nonetheless, in an entitlement theory of justice, the consent of a rights-holder is required before a right may be alienated (although, as in normal contract law, such consent to free assignability is presumed absent an express statement to the contrary); wrongdoing of a rights-holder is required before a right may be forfeited. Standing alone, "economic need" does not override these imperatives of justice.

73. See Restatement (SECOND) OF CoNTRACTS § 317 (1979):

(1) An assignment of a right is a manifestation of the assignor's intention to transfer it by virtue of which the assignor's right to performance by the obligor is extinguished in whole or in part and the assignee acquires a right to such performance.

(2) A contractual right can be assigned unless

(a) the substitution of a right of the assignee for the right of the assignor would materially change the duty of the obligor, or materially increase the burden or risk imposed on him by his contract, or materially impair his chance of obtaining return performance, or materially reduce its value to him, or

....

(c) assignment is validly precluded by contract.

74. See Restatement (SECOND) OF ConTracts, § 317 comment d (1979) ("When the obligor's duty is to pay money, a change in the person to whom the payment is made is not ordinarily material.").

75. See Restatement (Second) OF Agency, $\S 310$ coinment a (1957) ("The right of the principal to demand performance is subject to substantially the same limitations as the right of an assignee."). Ames viewed the law of undisclosed agency as closely related to the law of contract assignments and based the rights of the third party against the principal on an implied assignment to the third party of the agent's right of indemnification. See Ames, supra note 2, at 450-52. MüllerFreienfels criticizes Ames' approach because it cannot explain why "the undisclosed principal may be sued by the third party even when the agent has no right to an indemnity from the principal because their contract is void or the agent has acted contrary to his instructions." MüllerFreienfells, supra note 2, at 314 . In contrast, a consent theory bases the liability of the principal to the third party on the consensual flow of rights directly from the principal to the third party. Assignment principles only explain the liability of the third party to the principal. 
sis of a consent theory of contract can be conceived as an assignment of rights from $A$ to UP. As with the law of assignments, unless the undisclosed principal "assignee" notifies the third party "obligor" of the assignment, ${ }^{76}$ the third party's performance tendered to the agent satisfies the obligation to the undisclosed principal.

Goodhart and Hamson note that this rule is likely to create hardship and uncertaimty for the third party who "may be put into a difficulty by being in doubt whom he ought to pay."77 The Restatement (Second) of Agency suggests that the third party cannot refuse to pay the principal "[i]f the agency is admitted by the agent, and the agent sets up no personal claim in the transaction." 78 The same problem of uncertainty also exists in the law of assignments. Professor Farnsworth has noted that "[i]n applying the notification requirement, courts have sometimes seemed imsufficiently sympathetic to the position of the obligor."79 Thus, he recommends the adoption of the notification rules specified in section 9-318 of the U.C.C. ${ }^{80}$

Finally, Professor Geva describes ${ }^{81}$ another possible construction of the transaction in Illustration 3 that is both consistent with the entitleinents approach presented here and yet explains the adamant refusal of both juries in Scrimshire v. Alderton to follow the judge's repeated direction for the defendant. ${ }^{82}$ In Scrimshire, the agent, or "factor," received a higher commission from the primcipal by taking "the risque of the debts" arising from his credit sales. ${ }^{83}$ Geva suggests that:

the sale can be viewed as a sale of the principal's property, thereby creating a debt of the buyer to the principal. This sale is conceptually fol-

76. See Restatement (SECOND) OF AGENCY § 310 comment c (1957).

77. Goodhart \& Hamson, supra note 2, at 322 .

78. RESTATEMENT (SECOND) OF AGENCY $§ 310$ comment a (1957). The comment also states that if "there is doubt as to the existence of the agency or the respective rights to performance, the other party can interplead the principal and agent." Id.

79. E. FARNSWORTH, supra note 22, at 777.

80. U.C.C. $\S 9-318(3)$ (1977):

(3) The account debtor is authorized to pay the assignor until the account debtor receives notification that the amount due or to become due has been assigned and that payment is to be made to the assignee. A notification which does not reasonably identify the rights assigned is ineffective. If requested by the account debtor, the assignee must seasonably furnish reasonable proof that the assignment has been made and unless he does so the account debtor may pay the assignor.

81. Geva, supra note 14, at 57-60. In his excellent article, Professor Geva suggests that an undisclosed owner's ability to recover the price from the buyer is explained by his "property in the goods" rather than by a contractual relationship. Id. at 32 . His analysis is most harmonious with the entitlement theory that underlies a consent theory of contract. He uses this proprietary framework to explain an important issue that is beyond the scope of this article: when does a disclosed or undisclosed principal retain his right to the buyer's payment for goods upon the insolvency of the agent, and when does he lose this right to the creditors of the agent? See id. at 49 . 60.

82. 2 Stra. 1182, 93 Eng. Rep. 1114 (1743).

83. Id. at 1182, 93 Eng. Rep. at 1114. 
lowed by the extension of credit from the factor to the buyer. The effect of this credit extension is to substitute the debt of the buyer to the principal with a debt of the buyer to the factor, and to cast upon the factor an absolute obligation towards his principal with respect to the price of the goods. The debtor-creditor relationship thus established between the factor and the principal supersedes the latter's right in rem, and brings to an end his right to follow the property. ${ }^{84}$

According to this analysis, the principal has in this case consensually waived his nornal right to payment for his property from the buyer in return for a more reliable (viewed ex ante) debt of the agent. Instead of assuming the risk of nonpayment by the buyer, the principal instead assumes the risk of nompayment by the agent. When the judge in Scrimshire asked the second jury why they found for the defendant, they said that, "they thought from the circumstances no credit was given as between the owner and buyer, and that the latter was answerable to the factor only, and he only to the owner." 85

\section{Undisclosed Agency Law and the Freedom to Choose With Whom One Contracts}

The close theoretical relationship between undisclosed agency doctrine and the law of assignment also helps explain why and when persons may be "forced" to deal with parties to whom they might object. Consider again Illustration 4:

Illustration 4. Same facts as Illustration 1. After entering into the contract with $A, T$, an archcompetitor of $U P$, learns of $U P$ 's existence and identity, and refuses to deliver the goods. May $U P$ or $A$ sue $T$ for breach?

The law of assignments presumes that, unless the rights at issue are to be "personal," 86 contract rights are freely assignable. ${ }^{87}$ According to a consent theory of contract, the law governing undisclosed principals ought to be the same.

First, in the absence of an expression to the contrary or fraud, the mere fact that $A$ contracts with $B$ no more excludes the possibility that $B$ might in fact be an agent of $C$ than it excludes the possibihty that $B$ inight later assign her rights to another. ${ }^{88}$ Second, when the parties are silent on a particular issue, we must interpret that silence in light of any "background" understanding that may exist in the relevant commu-

84. Geva, supra note 14 , at 59 .

85. Scrimshire, 2 Stra. at 1183, 93 Eng. Rep. at 1115.

86. This restriction of free assignability is discussed infra text accompanying notes 101-06.

87. See 6 AM. JUR. 2D Assignments $\S 9$ (1963).

88. Goodhart \& Hamson, supra note 2, at 344 ("normally a person contracting in his own name does not, by that mere fact, make any representation that he is not contracting as trustee for, or for the benefit of, another."). 
nity. ${ }^{89}$ Normally it is presumed that any right is freely alienable. So unless there is an expressed reservation to the contrary, when one buys a car or some land, she obtains the right to resell it-that is, to alienate her rights to it-and to sell it to whomever she chooses.

Finally, a consent theory defines an agency relationship as a commitment by an agent to transfer to the principal any rights obtained on the principal's behalf. The fact that $A$ made the transfer commitment to $U P$ before $A$ obtained the rights from $T$ in no way undermines the normal presumption that the rights acquired from $T$ are fully transferable.

The argument that third parties should not be hable to an objectionable undisclosed principal gains its plausibility from the normal background assumption that a person with whom one deals is not the agent of another. Yet this assumption is not determinative here. Most contracting parties are indifferent to whether they are dealing with an agent or a principal, and so there is no reason to assume in Illustration 4 that $T$ objected to dealing with an agent qua agent rather than with a principal. In fact, what she really objected to was dealing with UP. Unless $U P$ had reason to know of this objection, ${ }^{90}$ the determinative issue concerns whether the rights traded by $T$ are subject to any restrictions on their future alienability. Therefore, when $T$ is silent on this question and $U P$ is unaware of $T$ 's particular objection to him, the background assumption favoring free alienability should govern.

For these reasons, undisclosed agency law should pernit $A$ secretly to represent anyone when contracting with $T$, provided that the obligations of $T$ are not adversely affected by the agency relationship, and are subject to any valid contract defense that $T$ might assert. The actual law of undisclosed agency is in accord..$^{91}$

In Illustration 4, $T$ does business with $A$, who, unbeknownst to $T$, represents $T$ 's archcompetitor UP. Upon discovering UP's existence, $T$ might accurately assert that when she entered the contract, she did so under the mistaken (tacit) assumption that $A$ did not represent $U P$. Under normal contract doctrine, however, $T$ 's mistaken assumption

89. See supra note 71 ; cf. Barnett, supra note $S$, at 303, 307-09, 315. 100.

90. In which case $T$ may assert a defense of mistake. See infra text accompanying notes 97-

91. Cf. Restatement (SECOND) of AGenCY § 304 comment a (1957) ("One contracting as agent for an undisclosed principal does not, by failing to mention a principal, represent that hc is not acting for one."); Prosper v. Smith, 67 Mont. 308, 215 P. 649 (1923) (where land was validly conveyed from $T$ to $A$, and $U P$ has taken possession of the land and made timely payments, UP may not be ejected on the ground that $T$ would have refused to deal with UP); Kelly Asphalt Block Co. v. Barber Asphalt Paving Co., 211 N.Y. 68, 105 N.E. 88 (1914) ( $T$ cannot escape liability on an implied warranty of merchantability on the ground that had he known the identity of the actual purchaser, he would have refused to make the sale); Parola v. Lido Beach Hotel, Inc., 99 A.D.2d 465, 470 N.Y.S.2d 44 (1984) ( $T$ may not escape liability on the contract by claiming ignorance of the undisclosed principal's existence). 
becomes a valid defense only if it was known to $A$ or $U P .{ }^{92}$ Thus, this defense would succeed if either $A$ or $U P$ knew or had reason to know that $T$ would not deal with UP_-perhaps because $T$ had refused to deal with $U P$ in the past. Only then would $T$ have a prima facie defense of mistake under normal contract primciples. A consent theory of contract supports this position, ${ }^{93}$ as does normal agency law. ${ }^{94}$

Assuming that $T$ can show that $U P$ or $A$ was or should have been aware of her reservation, $U P$ does have two potential responses to counter $T$ 's assertion of this defense. First, $U P$ might assert that $T$ was "consciously ignorant" of whether $A$ was an agent representing $U P$, and a party "bears the risk of mistake when ... he is aware, at the timie the contract is inade, that he has only limited knowledge with respect to the facts to which the mistake relates but treats his limited knowledge as . sufficient." 95 If this can be shown, normal contract doctrine would yield the conclusion that $T$ assumed the risk of doing business with UP. This determination would depend on the facts of a particular case and requires that $T$ be conscious or aware of her limited knowledge. Since there is no reason to suspect that $T$ had given any thought to the possibility that $A$ was $U P$ 's agent, $U P$ might not be able to estabhish this response to the defense of mistake. However, a conspicuous clause in the contract that permitted free assignability "to any party whatsoever" probably raises an inference of conscious ignorance. ${ }^{96}$

Second, where $T$ does not object to contracting with $U P$, but would liave asked a higher price had sle known of $U P$ 's existence, the defense of mistake slould be unavailable even where $U P$ is aware of $T$ 's attitude. There is no practical difference between this situation and one where a buyer las exclusive knowledge of the potential resale value of an item. The third-party seller's ignorance of UP's existence and identity simply deprives her of knowledge of the potential market value of the items. In reality, every seller who agrees to a price necessarily assumes the risk that the buyer might have been willing and able to pay more, just as every buyer assumes the risk that a seller would have been willing and able to accept less. Because such ignorance, whether conscious or not, is pervasive, it cannot undermine the normal moral significance of

92. Restatement (SeCoND) OF CoNTracts $§ 153(b)$ (1979).

93. See Barnett, supra note 5, at 308, 318.

94. See authorities cited supra note 21.

95. REstatement (SECOND) OF CoNTRACTS § 154(b) (1979).

96. Cf. Restatement (SECOND) OF AGENCY § 303 comment c (1957) (discussing evidentiary effect of nonassignment clause); Annot., 75 A.L.R.3d 1184 (1977) (same); see also Hanna Mining Co. v. Brletich, 286 Minn. 217, 175 N.W.2d 923 (1970) (stating in dicta that where option agreement provided that purchaser had the right to designate any grantees it wished, failure to disclose that purchaser was $A$ for $U P$ did not constitute misrepresentation warranting rescission). 
consent. ${ }^{97}$

After initial reluctance, ${ }^{98}$ courts have come to accommodate this pervasive fact of commercial practice. ${ }^{99}$ So too, in the undisclosed ageucy situation, absent an affirmative misrepresentation, ignorance of the potential market value of the item sold does not by itself support the defense of mistake. ${ }^{100}$ On the other hand, absent conscious ignorance (or other evidence of an assumption of risk), courts should allow a defense of mistake in extraordinary situations $m$ which one party deals with a second party who secretly represents a third party with whom the first party has previously refused to deal. In such extraordinary situations, the normal significance of manifested assent is undermined by $A$ or UP's knowledge that $T$ would not do business with $U P$.

\section{Undisclosed Agency and Inalienable Rights}

Even if the normal triangular flow of rights would transfer rights against $T$ to $U P$ and rights against $U P$ to $T$, there is one factor that may prevent this flow from occurring. In a consent theory of contract, if the rights imvolved are inalienable, then they cannot flow from one person to another even with the consent of the rights-holder. ${ }^{101}$ The only legal obligation that may properly arise from a commitment to exercise an inahenable right is the duty to pay money damages. ${ }^{102}$

In hight of this, consider the followimg situation:

Illustration 5. $T$ manifests an intention to be legally bound to paint a picture for $A$, who is secretly representing $U P$. $T$ discovers the existence of $U P$ and refuses to perform. May either $A$ or $U P$ compel performance?

The answer provided by a consent theory is clear: Since $A$ cannot compel performance of a personal services contract, neither can $U P$. In a consent theory, the right to use one's own body is inatienable and cannot under any circumstances be consensually transferred. ${ }^{103}$ Labeling such a

97. See Barnett, supra note 5, at 318 ("Traditional contract defenses can be understood as describing circumstances that, if proved to have existed, deprive the manifestation of assent of its normal moral, and therefore legal, significance.").

98. E.g., Sherwood v. Walker, 66 Mich. 568, 33 N.W. 919 (1887).

99. E.g., Nestor v. Michigan Land \& Iron Co., 69 Mich. 290, 37 N.W. 278 (1888); Wood v. Boynton, 64 Wis. 265, 25 N.W. 42 (1885).

100. Cf. Senor v. Bangor Mills, 211 F.2d 685 (3d Cir. 1954) (defendant-buyer used agent because potential sellers would have inflated price of nylon yarn had they known defendant's identity).

101. See generally Barnett, supra note 39.

102. See id. at 197-98.

103. It may, however, be forfeited. See id. at 186; see also Barnett, Restitution: A New Paradigm of Criminal Justice, 87 ETHIcs 279 (1977) (advocating that courts require criminals to make reparations to their victims); Barnett, The Justice of Restitution, 25 AM. J. JUR1SPRUDENCE 117 (1980) (elaborating the moral justification for restitution). 
commitment a "personal" one, ${ }^{104}$ the law of undisclosed agency and the law of assignments are in accord. ${ }^{105}$

In a consent theory, the only legal obligation that can arise from such a "personal" commitment is the commitment to pay damages upon nonperformance. Therefore, while $U P$ could not obtain the right to $T$ 's performance, the alienable right to money damages conditioned on nonperformance could be transferred from $T$ to $A$ and then to $U P .^{106}$

\section{Liability of Undisclosed Principals for Unauthorized Acts}

A consent theory of contract contemplates a system of staged pleadmgs based on a series of legally sufficient presumptions. ${ }^{107}$ Thus far, we have seen that in a consent theory $T$ is prima facie hable to UP if $U P$ can show that: (1) $A$ was UP's agent; (2) $T$ consented to a rights transfer to $A$; and (3) the subject of the agreement mvolved an alienable right. ${ }^{108} T$ may successfully assert defenses to her prima facie liability to $U P$, such as a defense of "satisfaction" (that she paid $A$ ) or a defense of mistake. 109 $U P$ may, however, be able to rebut a defense by an appropriate response. For example, $U P$ might respond to $T$ 's claim of mistake by pleadimg that $T$ was consciously ignorant and therefore assumed the risk of the mistake.

Conversely, $m$ a consent theory $U P$ is prima facie hable to $T$ if $T$ can show that: (1) $A$ was UP's agent; (2) $A$ consented to a rights transfer to

104. Goodhart \& Hamson, supra note 2 , at $338-45$, describe four distinct seuses in which a contract might be "personal." Only the fourth sense is coutemplated here:

So, normally, a contract to detiver goods is a contract to cause goods to be delivered and does not usually entail a duty on A himself to carry the goods to B's doorstep. But a duty may by contract be created in A to perform the burden with his own hand-e.g., by a contract to paint a portrait of B. Again, by a perfectly proper use of the word, this latter is called a personal contract, the former impersonal.

Id. at 340 .

105. For the undisclosed agency law relating to contracts for personal services, see RESTATEMENT (SECOND) OF AGENCY $\$ 310$ (1957) ("undisclosed principal . . can require the other party to render performance to him instead of to the agent, except in the case of personal services . . . "). For the law of assignments on this point, see Limb v. Federated Milk Producers Ass'n, 23 Utah 2d 222, 461 P.2d 290 (1969) (if contract made by $A$ involves elenents of personal trust and confidence as consideration from $A$, then UP cannot enforce it); E. FaRNSwORTH, supra note 22 , at 762 (courts have found a material change in the obligor's duty "if the obligor's duty is to perform services under the personal supervision of the other party to the coutract").

106. UP's claim for damages against $T$ would, of course, be subject to normal contract defenses, such as the inistake defense, discussed supra text accompanyiug notes 86-100.

107. See Barnett, supra note 5, at 309-10, 318 (describing the presumptive nature of consent); Epstein, Pleadings and Presumptions, 40 U. CH1. L. REv. 556 (1973) (describing the logic and operation of a systein of staged pleadings based on legal presumptious); see also Fletcher, The Right and The Reasonable, 98 HARv. L. REv. 949 (1985) (distingnishing between "structured" and "flat" legal theories).

108. See Barnett, supra note 39, at 184, 195-201 (discassing the distinction between the "subject" and "object" of a rights-transfer agreement).

109. Of course, other coutract defenses may be available as well. See RESTATEMENT (SECOND) OF AGENCY $\S 308$ (1957). 
$T$; and (3) the subject of the agreement was an alienable right. UP can defend that $T$ induced him to pay $A$, who then became insolvent. ${ }^{110}$ In a consent theory $U P$ has another defense that we have yet to consider: that $A$ 's consent was unauthorized. ${ }^{111}$ Notice that in asserting this defense, $U P$ does not deny that $A$ was his agent. Rather he is asserting an additional fact that undermines the normal significance of $A$ 's consent. ${ }^{112}$ What responses to this defense are available to $T$ ? The next two sections treat this issue.

\section{a. Apparent Ownership}

Under normal agency law, a principal is liable to third parties for contracts made by his agent where the agent either had actual authority (expressed or imphed) ${ }^{13}$ or has "apparent" authority. Apparent authority is "the power to affect the legal relations of another person by transactions with third persons, professedly as agent for the other, arising from and in accordance with the other's manifestations to such third persons." 114

In a systein of staged pleadings, apparent authority would be viewed as a response to a defense by a primcipal that his agent's acts were unauthorized. In other words, agents are presumed to be acting in an authorized inanner; primcipals must plead and prove that this was not the case. Even if the principal proves the agent had no actual authority, however, third parties may still recover if apparent authority can be shown.

Now consider the following situation:

Illustration 6. UP installs $A$ as the manager of his retail store. $A$ 's name appears above the door. Unbeknownst to $T, U P$ instructs $A$ that he may not sell goods to $T$. Contrary to instructions, $A$ agrees to sell certain goods to $T$. UP refuses to honor the sales agreeinent. Can $T$ sue $U P$ for breach of contract?

In Illustration 6, actual authority is clearly lacking, since $A$ was expressly forbidden from selling anything to $T$, and was therefore acting outside his authority in doing so. May $T$ respond that $A$ had apparent authority?

The doctrine of apparent authority is unavailable to $T$ in the undis-

110. In English law, where UP's settlement with $A$ does not discharge $U P$ 's obligation to $T$, the fact that this settlement was induced by $T$ does provide UP with a defense. See supra text accompanying notes 11-13.

111. See, e.g., Industrial Mfrs. v. Bangor Mills, 283 A.D. 113, 116-17, 126 N.Y.S.2d 508, 511 (1953):

The general rule is recognized that an undisclosed principal is liable to third parties on contracts made in his behalf by his agent acting within his actual authority. It is equally well established that the undisclosed principal is not bound by a contract made by his agent beyond the scope of his actual authority.

112. That is, it defeats UP's normal liability. $A$ 's contractual liability to $T$ remains unaffected.

113. See Restatement (SeCOND) of Agency $§ 7$ and comments (1957).

114. Id. $§ 8$. 
closed agency context, and so cannot be applied to Illustration $6 .{ }^{115}$ As traditionally understood, apparent authority exists only when $T$ believes that $A$ is an agent, and the principal has "cloaked" $A$ with more authority than $A$ was actually given. According to the Restatement (Second) of Agency: "Apparent authority results from a manifestation by a person that another is his agent, the manifestation being made to a third person and not, as when authority is created, to the agent. It is entirely distimct from authority, either expressed or implied."116 The doctrine of apparent autlority requires the principal to create a belief in the third party that another is lis agent. In the realm of undisclosed agency, lowever, $U P$ cannot create the appearance that $A$ is his agent, precisely because his identity and existence are unknown to $T$. Quite the contrary, $U P$ creates the appearance that $A$, who really is his agent, is not an agent at all, but is the principal. ${ }^{117}$

Although the doctrines of actual or apparent autliority are unavailable to her, the law of undisclosed agency sometimes allows $T$ to recover from $U P$ in this situation. ${ }^{118}$ The rationale offered by the Restatement in support of this position is revealing. After reaffirming the absence of actual and apparent authority, the autliors then suggest: "There may be, however, an apparent ownership, and from this there may be a power to affect the imterests of the principal aside from any rule of agency." 119

This theory of recovery from $U P$ is not, then, strictly speaking, a pure agency theory at all, since neitlier actual nor apparent autliority exists. Nor is it a pure contract theory, since $U P$ lias neither actually nor apparently consented to be bound. ${ }^{120} U P$ lias not empowered $A$ to alien-

115. See id. $\S 8$ comment a ("Apparent authority exists only with regard to those who believe and have reason to believe that there is authority; there can be no apparent authority created by an undisclosed principal.").

116. Id.

117. See supra note 115.

118. See Restatement (SECOND) OF AGENCY $\$ 194$ (1957) ("A general agent for an undisclosed principal authorized to conduct transactions subjects his principal to liability for acts done on his account, if usual or necessary in such transactions, although forbidden by the principal to do them."); see, e.g., Dotson v. Grice, 98 N.M. 207, 647 P.2d 409 (1982) (general agent of UP can bind $U P$ despite lack of both authority and apparent authority).

119. RESTATEMENT (SECOND) OF AGENCY § 194 comment a (1957); see also Ferson, Undisclosed Principals, 22 U. CIN. L. REv. 131, 158 (1953) ("The agent of an undisclosed principal has apparent ownership of property he holds for his principal.") (emphasis in original). Not coincidentally, I think, Ferson also adopts a view akin to a consent theory of contract, albeit without explicitly acknowledging the crucial entitlements underpinning. See M. FERSON, THE RATIONAL Basis of CoNTracts aNd Related Problems IN Legal ANalysis 60-83 (1949); Ferson, Fiction vs. Reality, in re Contracts: A Survey, 7 VAND. L. REv. 325 (1954).

120. Of course, in a consent theory, UP's hability does depend upon $A$ having manifested assent to be bound. This element of the prima facie case is contractual. In a system of staged pleadings, the prima facie case of obligation here would be a mix of both contract and agency theories: (1) $A$ manifested assent to transfer rights to $T ;(2)$ the subject of the agreement was an alienable right; and (3) $A$ is the agent of UP. T's response to UP's defense that $A$ 's consent was unauthorized, however, 
ate his rights to the goods. Moreover, a tort theory of fraud might be difficult to establish. As UP may have had no intent to misrepresent the extent of $A$ 's authority to $T$, the requisite scienter may be lacking.

This situation is strikingly similar to the problem of explaining the objective interpretation of contracts. The objective approach holds a promisor liable for the appearance of assent, even though he may neither have intended to assent, nor imtended to deceive the promisee. A consent theory utilizes its entitlements underpinnings to explain an objective approach. Entitlements exist to establish safe and discernable boundaries within which individuals may exercise personal discretion in pursuit of happimess. In establishing these boundaries, both property and contract law must utilize outwardly manifested behavior. ${ }^{121}$

Therefore, the Restatement authors' suggested rationale that what has been created is "apparent ownership" is theoretically insightful. For what $U P$ has done is to create the appearance of an entitlement- or ownership-transfer, and outsiders are entitled to rely on this appearance. Conversely, where UP has created no such appearance, the unauthorized acts of an agent will not bind an undisclosed principal. ${ }^{122}$

In an entitlements theory, just as "apparent assent" can be binding in contract law and "apparent authority" can be binding in agency law, "apparent ownership" can be binding in property law-and for the same reason. As with apparent assent and apparent authority, a person's conduct has created the appearance of a distribution of rights or a "boundary" upon which third parties are entitled to rely. Thus, apparent

need not be contractual in nature. Richard Epstein makes the same point in his discussion of the plaintiff-seller's response to the contract defense of infancy, viz that the minor was provided with necessaries:

It cannot be said simply that the defendant "is bound, not because he has agreed, but because he has been supplied." The case has two "becauses," the first of which is the agreement to purchase. Had there been no agreement between the parties, the plaintiff might still be able to recover, but not on the simple allegation that he provided the defendant with necessaries. The allegation presupposes the two prior stages of the argument, the first of which alleged the agreement. By itself, it does not state a cause of action. The formal rules of pleading do not provide the basis of a "pure" theory of quasicontract, apart from agreement, but they do help identify those situations in which one is necessary for the plaintiff to recover.

Epstein, supra note 107, at 571 (footnote omitted).

121. Barnett, supra note 5, at 303 ("Only a general reliance on objectively ascertainable assertive conduct will enable a system of entitlements to perform its allotted boundary-defining function.").

122. See, Senor v. Bangor Mills, 211 F.2d 685, 688 (3d Cir. 1954):

The typical application of this rule is to a going concern with an established place of business and obvious assets operated by one who ostensibly is the proprietor but secretly is agent for an undisclosed principal. In such cases liability is imposed upon the undisclosed principal because he has placed the agent in such apparent relationship to an observable enterprise as is likely to induce reliance upon him as a responsible proprietor. But there is no rational or equitable basis for such a doctrine unless the person dealing with the agent finds him in charge of a "business" in this sense of a functioning enterprise with observable assets.

(citations omitted). 
ownership can be created in a manager of a business, ${ }^{123}$ in a person entrusted with possession of goods who normally has the right to sell goods in his possession, ${ }^{124}$ or in a person entrusted with title ${ }^{125}$ or other commercial docuinents. ${ }^{126}$

\section{b. Restitution}

We now address one last "hard case" of undisclosed agency:

Illustration 7. UP installs $A$ as the manager of his hotel and tavern. $A$ 's name appears above the door. $U P$ instructs $A$ that he may purchase only beer and ale for the tavern and that all other supplies will be purchased by $U P$. Contrary to instructions, $A$ purchases cigars, bovril, and other items from $T$. Is $U P$ hable to $T$ for $A$ 's unauthorized purchases?

Here, just as in Illustration 6, actual authority is clearly lacking, since $A$ was expressly forbidden froin buying anything other than beer and ale, and was therefore acting outside his authority in doing so. Illustration 7 is based on the famous case of Watteau v. Fenwick. ${ }^{127}$ In the actual case, the defendant argued that both actual and apparent authority were absent, yet the court held that the UP was liable, stating:

Otherwise, in every case of undisclosed principal, or at least in every case where the fact of there being a principal was undisclosed, the secret limitation of authority would prevail and defeat the action of the person dealing with the agent and then discovering that he was an agent and had a principal. ${ }^{128}$

Could an apparent ownership theory again be used to explain the result in Watteau v. Fenwick and Illustration 7? Perhaps not. After endorsing an apparent ownership approach to explain a situation like Illustration 6, Professor Ferson disputed whether such a theory explained the liability of $U P$ in Illustration 7.

What does Hunble's name over the door proclaim? Freely translated, it says "Humble owns this stock of goods." Fenwick [the true owner] is responsible for that statement. And so, if Humble sells goods from the store-even though he has been prohibited froin doing so-the buyer will be protected. ... But Humble's name over the door does not say, or even

123. RESTATEMENT (SECOND) of AGENCY § 195 (1957) ("An undisclosed principal who entrusts an agent with the management of his business is subject to liability to third persons with whom the agent enters into transactions usual in such businesses and on the principal's account, although contrary to the directions of the principal."); see, e.g., Johnson v. Fischer, 108 Ill. App. 2d 433, 247 N.E.2d 805 (1969) (absentee owner of farm is liable for repairs made by contractor where repairs were ordered by tenant who appeared to own, or have authority to order repairs on, the property); Holınan-O.D. Baker Co. v. Pre-design, Inc. 104 N.H. 116, 119, 179 A.2d 454, 456 (1962) (quoting with approval RESTATEMENT (SECOND) OF AGENCY § 195).

124. RESTATEMENT (SECOND) OF AGENCY § 201(2)-(3) (1957).

125. Id. at $\S 201 \mathrm{~A}$.

126. Id. at $\S 202$.

127. [1893] 1 Q.B. 346.

128. Id. at 349. 
intimate, that Humble can bind Fenwick in a personal obligation. ${ }^{129}$

True, Ferson's construction might be questioned. A third party dealing with the owner of a business might, for example, reasonably assume that the stock of goods would be available to satisfy a legal judgment (subject perhaps to another creditor's recorded security interest). At the very least, the third party does not believe that he is relying solely on the personal credit of the apparent owner. If the business is a corporation, the prevailing assumption is that the owner is not personally liable; hability is placed on the corporation. Still, Ferson's argument suggests that an apparent ownership rationale may not be as coinpelling here as it was in Illustration 6. An entitlement theory based on property rights, however, does provide $T$ with an additional response that would not have been available to her in Illustration 6 .

Consider Illustration 7 froin the seller's point of view. $A$ 's cominitment to buy $T$ 's goods creates a contractual claim against $A$, since $A$ manifested assent to be legally bound to pay for the goods. While "apparent ownership" may or may not justify UP's liability, $A$ 's receipt of the goods on $U P$ 's behalf gives rise to an additional theory of UP's liability. If $A$ possesses the goods as UP's agent (and not for his personal use), then $U P$ has received the beneficial use of T's goods. In Watteau v. Fenwick, $A$ could sell the cigars and bovril in UP's tavern for UP's benefit. $U P$, therefore, is indebted to $T$ for the goods received. The principal's common law obligation to pay for goods received by his agent for his benefit is even older than the law of undisclosed agency. ${ }^{130}$ While the ancient cases do not address the undisclosed principal situation,

the focus of all of them seems to be on the objective fact that the goods were purchased or came to the use of another, and not on the seller's knowledge of the buyer's status. ... Whatever the rationale, it emerges from these cases that the purchase of goods to the use of someone inay confer the property directly upon that person. Since hability in debt is a matter of acquisition of legal title, that person will be charged with the debt that arises, even though he never promised the seller payment. ${ }^{131}$

In Illustration 7 , an entitlement theory suggests that, assuming the prima facie cause of UP's liability is established and notwithstanding that $A$ acted without $U P$ 's authority, when $A$ receives goods from $T$ for $U P$ 's benefit, it is $T$ 's property rights in the goods that give rise to UP's duty to

129. Ferson, supra note 119 , at 138. Ferson contends that Fenwick is liable on either a respondeat superior or a ratification analysis; see id. at 139-40; see also Lewis, The Liability of the Undisclosed Principal in Contract, 9 CoLUM. L. REv. 116, 122 (1909) (denying that simply clothing the agent in the appearance of wealth gives rise to any obligation in the undisclosed principal).

130. See Geva, supra note 14 , at $39-45$ (discussing cases).

131. Id. at 44-45; see also Lewis, supra note 129, at 132 ("If the undisclosed principal had been sued in the action of debt, the fact that he was not a party to the transaction from which the rights and obligation sprang would have been immaterial. ... The obligation enforced in the action of debt was the duty to pay. This duty did not always arise out of a promise."). 
pay for them. Modern theorists and judges would classify this situation in terms of restitution, benefits retained, or unjust enrichment. ${ }^{132}$ Yet it is not enough that $U P$ was enriched at $T$ 's expense. Only an entitlements theory is able to explain the injustice of the principal's enrichment. In Illustration 7, (1) UP consented to an agency relationship with $A$; (2) $A$ consented to buy $T$ 's goods; (3) $T$ delivered her goods to $A$; and (4) $U P$ received the benefit of $T$ 's goods. ${ }^{133}$ In short, a property rights-based entitlement theory puts the res ${ }^{134}$ back in restitution. ${ }^{135}$ Thus, whether best explained by the "apparent ownership" of the agent-buyer or the property rights of the third party-seller in her goods giving rise to a restitution-based claim, $U P$ 's liability for $A$ 's unauthorized purcliase in Illustration 7 is explained by the entitlement theory that underlies a consent theory of contract.

\section{III}

\section{ASSUMPSIT AS THE SOURCE OF THE ANOMALY}

If the paradigm case and the hard cases of undisclosed agency can all be explained by a consent theory of contract, why has this area of law seemed to be anomalous to so inany for so long? The foregoing analysis of Illustration 7 points to the answer: the use of assumpsit, a promisebased theory of contract, as a means to escape the inflexibility of the previously available writs, and the subsequent abandonunent of the action of debt. ${ }^{136}$

Assumpsit bases contractual liability on the voluntary assumption of a duty to act or refrain from acting. ${ }^{137}$ In other words, liability is based

132. See, e.g., N.K. Parrish, Inc. v. Southwest Beef Indus. Corp., 638 F.2d 1366, 1371 (5th Cir.) ("the [undisclosed] principal may be liable, even when the agent acts without authority, when the principal retains the benefits of the transaction."), cert. denied sub nom. Bluemle v. N.K. Parrish, Inc., 454 U.S. 1047 (1981).

133. Cf. Müller-Freienfels, supra note 2, at 307:

It is not only the fact that the principal has got an objective enrichment which justifies his direct liability to the third party-corresponding to the action of debt. He has also consented. The undisclosed principal is responsible directly to the third party because he has authorised the agent. He has enabled him to act as his agent and so made him competent to exercise his rights and duties.

134. "RES ... in old English law it is said to have a general import, comprehending both corporeal and incorporeal things of whatever kind, nature, or species." BLACK's LAW DicTIONARY 1172 (5th ed. 1979); see Geva, supra note 14, at 38-39 (describing the common law use of the concept of res to justify the right to the proceeds of sale).

135. "RESTITUTION ... 1. The action of restoring or giving back something to its proper owner, or of making reparation to one for loss or injury previously inflicted. . . 2 . . A restoration of something taken from another," 8 OXFORD ENGLish DicTionARY 551 (1970).

136. Cf. Müller-Freienfels, supra note 2, at 303-09 (explaining the anomalous character of undisclosed agency through the consideration doctrine associated with assumpsit).

137. See generally A. Simpson, A History of the COMMON LAw OF CONTRACT: THE Rise OF THE ACTION OF AsSUMPSIT (1975) (describing the rise of assumpsit and the eclipse of debt, detinue, and covenant as the principal modes of contractual enforcement); Levontin, Debt and 
on injury caused by the failure to perform a promise. While the doctrine of consideration and the Statute of Frauds were devised to restrict assumpsit's potentially limitless scope, actions in contract were nonetheless severed from the property rights that had provided the basis for actions in debt, detinue, and those covenants secured by a penal bond. ${ }^{138}$

As long as contract law is conceived of as inerely "proinissory," anomalies like the law of undisclosed agency will persist. If contractual obligation is viewed as promise-based-that is, derived from the (binding) promise $A$ made to $T$ and the reciprocal promise $T$ made to $A$-it remains a mystery why $U P$, to whom $T$ inade no promise whatsoever, has any contractual rights against $T$. Likewise, $U P$ made no promise whatsoever to $T$, enforceable or otherwise. In the absence of a direct promise, theorists inust then search for estoppel or enrichınent theories to explain hability, soinetimes to no avail.

A consent theory of contract is entitlements-based, not promisebased. Promises may or may not cause the transfer of entitleinents. And entitlements may be consensually transferred without a promise-that is, without a "manifestation of mtention to act or refrain from acting in a specified way, so made as to justify a promisee in understanding that a commitment has been made." 139 When entitleinents to resources have been consensually transferred by promise or otherwise, the actual distribution or "holdings" of resources must be brought into accordance with entitlements. It does not ordinarily inatter that rights were transferred from $U P$ to $T$ as a result of two distinct rights-transfer agreements such that $U P$ and $T$ were not parties to the same contract. If $T$ is now entitled to something that $U P$ possesses, then a redistribution is warranted. And since $A$ was a party to a contract with $T, T$ may seek inoney dainages from $A$ as well. Nor does it ordinarily inatter that $U P$ acquired his right to $T$ 's money indirectly through $A$. If $T$ does not pay, then $U P$ inay enforce his entitlement by suing $T$ directly.

\section{IV}

\section{Tradition, REASON, AND THE Evolution of COMMON LAW DOCTRINE}

The doctrine of undisclosed agency developed during a period dominated first by will or assent theories and then by reliance and benefit

Contract in the Common Law, 1 ISRAEL L. REv. 60 (1966) (describing the medieval actions and their eclipse and advocating the contemporary feasibility and advantages of debt).

138. See authorities cited supra note 137.

139. RESTATEMENT (SECOND) OF CONTRACTS \& 2(1) (1979). For example, an "as-is" cash sale of goods transfers entitlements, but involves no promises of any kind. For this reason, E. Allan Farnsworth concludes that this transaction is not contractual. See E. FARNSworTH, supra notc 22, at 4 . 
theories. During this time, it was widely known that none of these theories satisfactorily accounted for this body of law. ${ }^{140}$ Yet the doctrine developed despite this, and in a reinarkably coherent manner. There is a lesson in this for legal theorists.

It is true that we need legal theory to help shape and rationalize the decisions of courts, and it is true that individual judges are often illequipped to engage in much rigorous theory. But judicial decisions can be the source of important information for legal theorists. The countless judges who developed the law of undisclosed agency never heard of a consent theory of contract. And they might very well have accepted other doctrines that a consent theory would reject. Yet, in spite of their own theoretical knowledge and by the force of their experience and sheer intuition, they produced a body of doctrine that only a consent theory can adequately explam.

Elsewhere, I have argued that judges seek a form of moral knowledge when devising rules that will both resolve present disputes and avoid future ones. ${ }^{141}$ That is, they seek to deterinine how a dispute ought to be resolved. Judges have acquired this knowledge in two ways: by tradition and by reason. Two important sources of tradition are precedent and commercial custom. Precedent is derived from the decisions of countless other judges. These decisions consist both of adjudicated outcomes and the judges' explanations of those outcomes. Commercial custom is derived from the "situation sense" or practical wisdom of countless traders in a particular commercial commumity coupled with their experience with the strategic behavior of others.

There is a critical evolutionary process at work here, one that is capable of producing what has been called a "spontaneous order." ${ }^{142}$ Countless persons must concur before any decision becomes a "majority rule" or a "custom". The resulting consensus is not right solely because it is a consensus; rather, by capturing the "local" wisdom of innumerable persons, it is provides important insights or knowledge about what is right in particular situations.

Pure tradition alone, however, is not enough. Although the insight provided by these processes is the product of the experience and rational faculties of its participants, and as such deserves great respect, even the multitude can be wrong. Instead of rejecting erroneous decisions, traditional processes can sometimes reinforce them. The task of judges and

140. See authorities cited supra note 2.

141. See Barnett, Foreword: Judicial Conservatism v. A Principled Judicial Activism, 10 HaRv. J.L. \& PUB. POL'Y 273 (1987).

142. While spontaneous order theory has been an essential component of liberal social thought for centuries, its most prominent contemporary exponent is F.A. Hayek. See generally F.A. HAYEK, supra note 38. For a recent and provocative analysis of spontaneous order processes, see $\mathbf{R}$. SUGDEN, THE ECONOMICS OF RIGHTS, COOPERATION AND WeLFARE (1986). 
scholars is to critically evaluate the "received wisdom" or, in the words of Lon Fuller, "to separate the tosh from the essential."143 Without critical imput, tradition would not evolve or progress.

Legal theory apphes reason to systematize and reform the rules and practices produced by evolutionary processes. Most legal theorists do not presume that they are capable of creating an entire body of law from whole cloth. Rather, they take the time that most judges cannot afford, often using special techniques to evaluate critically the answers to legal probleins that tradition has graciously provided. Sometimes the traditional answers are shown to be either wrong or at least inconsistent with traditional answers to other problems. Theorists then strive to correct perceived error and reconcile perceived inconsistencies. I have called the persons who drive this process of legal evolution "the electorate of law."144

If the "anomaly" of undisclosed agency law arises from the conflict between two spontaneously developed doctrines-undisclosed agency law and the modern doctrine of assumpsit-it has persisted because modern contract theories have taken assumpsit as given. Such theories, therefore, uneasily conclude that the doctrines developed to resolve undisclosed agency problems are "anoinalous." It is a sign of the vitality of the "electorate of law" that it has not sacrificed the practical wisdom of this body of rules on the altar of contract theories devised to rationalize a conceptual mistake.

A legal theory needs much more than a correspondence with legal practice to be proved right. The function of legal theory is not simply to predict or explain outcomes of lawsuits, but to justify them. ${ }^{145}$ Nonetheless, the fact that a consent theory of contract succeeds in explaining the law of undisclosed agency where other theories of contractual obligation have failed is surely a mark in its favor. Moreover, if a consent theory

143. Fuller, The Forms and Limits of Adjudication, 92 HARv. L. REv. 353, 356 (1978). As Fuller explained:

The ideals that keep a social institution alive and functioning are never perceived with complete clarity, so that even if there is no failure of good intentions, the existent institution will never be quite what it might have been had it been supported by a clearer insight into its guiding principles. . . . Surely there is a great deal of tosh-that is, superfluous rituals, rules of procedure without clear purpose, needless precautions Id. preserved through habit-in the adjudicative process as we observe it in this country.

144. Barnett, supra note 141, at 286.

145. See R. Dworkin, LAw's Empire 110 (1986):

A full political theory of law, then, includes at least two main parts: it speaks both to the grounds of law-circumstances in which particular propositions of law should be taken to be sound or true-and to the force of law-the relative power of any true proposition of law to justify coercion in different sorts of exceptional circumstance.

(emphasis in original); see also Nance, Legal Theory and the Pivotal Role of the Concept of Coercion. 57 U. CoLo. L. REv. 1 (1985) (discussing the centrality of coercion in legal analysis and the requirement of justification). 
and its property rights foundations are correct, then the "anomalous" rules devised by judges to regulate the relations of undisclosed principals, their agents, and those with whom they contracted are not only explicable. They are justified. 
